\title{
3D Printed Scaffolds as a New Perspective for Bone Tissue Regeneration: Literature Review
}

\author{
Raquel Couto de Azevedo Gonçalves Mota ${ }^{*}$, Emerson Oliveira da Silva1, \\ Felipe Fortes de Lima², Lívia Rodrigues de Menezes' ${ }^{1}$, Antonio Carlos Santos Thiele ${ }^{1}$ \\ ${ }^{1}$ Instituto de Macromoléculas Professora Eloisa Mano, Universidade Federal do Rio de Janeiro, \\ Rio de Janeiro, Brazil \\ ${ }^{2}$ Universidade Federal do Rio de Janeiro Pólo Xerém, Estr. de Xerém, 27-Xerém, Duque de Caxias-RJ, \\ Rio de Janeiro, Brazil \\ Email: *raquel@nano.ufrj.br
}

Received 18 July 2016; accepted 28 August 2016; published 31 August 2016

Copyright (C) 2016 by authors and Scientific Research Publishing Inc.

This work is licensed under the Creative Commons Attribution International License (CC BY). http://creativecommons.org/licenses/by/4.0/

c) (i) Open Access

\section{Abstract}

Due to the high incidence of bone fractures in the population, it became necessary to produce scaffolds that are able to assist in tissue regeneration. It is necessary to find an appropriate balance between the mechanical and biological properties, in order to mimic the natural tissue, these properties are directly related to the architecture and their degree of porosity, as well as the size of their pores and their interconnectivity. In this perspective, the 3D printing stands out, where the structure is obtained layer by layer, according to a predetermined computational model which provides a greater control of architecture and scaffold geometry and overcomes, in this way, the limitations of traditional techniques of scaffolds manufacturing. In this way, the objective of this seminar is to present the state of the art of the polymer scaffolds produced by 3D printing and applied to bone tissue regeneration, highlighting the advantages and limitations of this process.

\section{Keywords}

Scaffolds, 3D Printing, Tissue Engineering, Bone Tissue

\section{Introduction}

Scaffolds are three-dimensional biocompatible structures that can mimic the properties of the extracellular ma-

${ }^{*}$ Corresponding author.

How to cite this paper: de Azevedo Gonçalves Mota, R.C., da Silva, E.O., de Lima, F.F., de Menezes, L.R. and Thiele, A.C.S. (2016) 3D Printed Scaffolds as a New Perspective for Bone Tissue Regeneration: Literature Review. Materials Sciences and Applications, 7, 430-452. http://dx.doi.org/10.4236/msa.2016.78039 
trix (ECM) of a given tissue, like mechanical support and bioactivity, which provides a platform for cellular adherence, proliferation and differentiation. For that reason, scaffolds are frequently used in tissue engineering with the intention of assisting the regeneration of a damaged tissue, and a major application in bone regeneration [1]-[4].

The traditional methodology of scaffolds manufacturing includes techniques such as: solvent casting [5]-[7], porogen leaching [8] [9], gas foaming [10], lyophilization [11], and electro and wet spinning [12] [13] or a combination of these techniques. Even though these techniques are largely applicable in the field, they can currently bring many disadvantages, including the use of toxic organic solvents, difficulty in removing residual solvent particles from the scaffolds matrix [14]-[18], long manufacturing period, low reproducibility of the techniques [19] and manufacturing of irregular pores and thin structures [20]. The solvent casting technique, for instance, depends on the shape of the mold, making it impossible to readjust the level of porosity and the size of the pores without making and using a new mold [21].

A great variety of studies show that the cell-material interaction plays an important part on tissue engineering, helping the cells migrate, proliferate and differentiate [22]-[26]. Therefore, the size, design and interconnectivity of the pores are essential factors that need to be considered when fabricating a scaffold [19]. 3D (three-dimensional) printing allows more control of the scaffold's architecture, because the printed object is faithful to the developed model. Besides that, the modelling and printing processes are very fast and easy, which allows the researchers to conduct many tests [21]. Therefore, scaffolds with different designs and pore sizes can be made and tested, allowing them to become a platform to study the effects of the geometry and architecture of those structures in both cellular response and mechanical behavior of those structures [27].

Due to the improvements on the control of the scaffolds achieved through 3D printing, those scaffolds can be modelled according to specific and individual defects of each patient with the use of Computed Tomography (CT) and Magnetic Resonance Imaging (MRI) [28]-[30], through the use of modelling strategies such as parametric modelling, in which the models are created using pre-defined parameters, the created design can be easily and quickly adapted to other patients, without the need to make a new scaffold from scratch. The three-dimensional model can be altered and exchanged between researchers and other health professionals, which makes it easier to refine them and to create new structures [31]-[33].

Likewise previous reviews on this subject, this work intends to present the state of the art of 3D-printed polymeric scaffolds, presenting and explaining every technique, but takes it a little farther than its predecessors by focusing on the advantages and limitations of each process, and highlighting its use for bone tissue engineering. And, as the main goal is to produce a viable scaffold; this review also focuses on the possibility of using nanomaterials during the 3D printing process to improve the scaffold's mechanical strength and enhance other physical properties.

\section{Scaffolds for Bone Regeneration}

The bone, a prominent tissue, not only plays an important role in the movement and in the protection and support of other organs but also plays a key role in controlling critical human physiological functions, including mineral storage, blood cell formation, homeostasis, and blood $\mathrm{pH}$ regulation [34]. The bone tissue is made up of several different elements, of which can be highlighted the osteoblasts, osteocytes and osteoclasts. The first two are responsible for bone formation, while the last one is responsible for the reabsorption of existing bone tissue with the intention of remodeling it, which guarantees the balance of the ions involved in bone neoformation in the body. When these effects are combined in one full process, it is possible to say that the bone is made up by a dynamic tissue that can maintain a constant cycle of remodeling/regeneration. However, its ability to regenerate is limited. So, big defects cannot be spontaneously fixed by the body [35] [36]. Besides, in cases of patients with limited healing, such as those with diabetes or poor nutrition, its regeneration is very slow and does not suppress the needs in cause [37]. Since the limits of this regeneration and the fact that aging reduces the neoformation ability of the bone tissue, bone fractures present a serious public health concern [38]. All things considered, the need for tissue regeneration technology grows dramatically along with the world population and the increase in life expectancy. Degenerative bone diseases and fractures are known to affect millions of people worldwide. Currently, it is expected that the percentage of people over 50 years of age affected by bone diseases will double by the year 2020 [39], These fractures are the main cause of the high rate of morbidity and physical disability among elderly patients, which drastically decreases the quality of their lives [40] [41].

Bone graft is second only to blood as the most commonly transplanted tissue [42]. Approximately 500,000 
bone grafting procedures are performed annually in the United States alone with about 2.2 million procedures worldwide, generating a sale of about $\$ 2.5$ billion per year [43]. The problem with using grafts as substitutes for the original tissue is that complications arise from the graft becoming loose, to inflammation/local infection followed by osteolysis, the death of the bone tissue, which only increases the existing damage [44] [45]. In addition, synthetic materials do not interact well with the human organism and fail with time due to fatigue or an adverse reaction of the organism. Therefore, there is a need for a new generation of biodegradable and biocompatible implants to substitute the traditional ones, eliminating the need to subject the patient to a second surgery to remove the implant and all the risks associated with that second surgical procedure [46]-[49].

The concept of tissue engineering emerged in the year 1990 to deal with the limitations of grafts and tissue repair, focusing on methods to synthesize and/or regenerate tissue and amplify its functions in vivo. It consists in transplanting biofactors (cells, genes or proteins) along with a three-dimensional porous material, which is biocompatible and biodegradable, known as the scaffold [50]. The biofactors stimulate the tissue repair, while the role of the scaffold and its porous architecture is far from passive since it mimics the properties of ECM, preserving the volume of the tissue and providing mechanical support for the cells to adhere and proliferate [35] [51] [52].

Whereas in the late $1990 \mathrm{~s}$ tissue engineering envisioned the replacement of whole tissues or even organs, today there is a tendency towards preventive medicine. All things considered, the greatest impact of tissue engineering in the next decade might be in vitro physiological models to study disease pathogenesis, thus allowing the development of drugs that can eliminate or reduce the need for tissue replacement [53].

Tissue regeneration is an interdisciplinary area that intends to combine knowledge of cellular biology, biomaterials and chemical factors to create a functioning scaffold [54]. The construction of an ideal scaffold requires: i) biocompatibility, since the scaffold should support cellular activity, making it easier for cells to adhere, proliferate and differentiate, without causing toxic effects to the regular tissue, ii) controlled kinetic biodegradation so that the scaffold degrades as the tissue regenerates and takes its place, iii) enough mechanical strength for the scaffold to withstand sterilization, handling and transportation before the surgery, and also physical force in vi$v o$, and at last it requires, iv) interconnectivity between the pores that allows the diffusion of essential nutrients and oxygen so that the cells may survive [55].

Kuboki et al. (1998) showed the need for porosity in bone regeneration using solid and porous particles of hydroxyapatite for BMP-2 delivery in a rat ectopic model: no new bone formed on the solid particles, while in the porous scaffolds direct osteogenesis occurred [56].

The challenge in the field of porous scaffolds is developing one that matches the biomechanical properties of bone and that has sufficient bioactivity to stimulate new bone regeneration. The pores not only play a significant role in allowing cell penetration and migration, but also significantly influence the physical properties of the scaffold [57] [58]. For instance, the increase in the porosity is known to decrease exponentially the mechanical properties, whereas on the other hand, the increased porosity increases permeability and, consequently, bioactivity [59]. With that in mind, Zhang and collaborators (2009) have measured the mechanical properties of ceramic scaffolds made by stereo lithography for bone regeneration, with a compression test under axial tension at a speed of $1 \mathrm{~mm} / \mathrm{min}$. Different scaffolds were obtained, with the volume of porosity ranging from $0 \%$ to $60 \%$ of the piece's total volume. Based on these results, the authors were able to observe that the compression module for the piece with $30 \%$ porosity is $18.4 \mathrm{MPa}$, and that this value is similar to the resistance of the natural bone, so it can supply a good mechanical structure for cellular repair. The study conducted by Bose and collaborators (2013) shows the mechanical properties of ceramic scaffolds 3D printed by conventional and microwave selective laser sintering and shows similar results, which shows that denser scaffolds show better final mechanical properties in both forms of sintering [35].

Even though the porosity is a negative aspect in mechanical terms, its increase is related to the growth of its bioactivity, because the bigger the porosity, the bigger the available surface area that encourages cellular adherence and proliferation [60]. In this sense, the study conducted by Lin and collaborators (2014) intended to evaluate the relationship between the scaffold's porosity and the cellular activity stimulated by them. For that, polyethylene glycol (PEG) scaffolds were produced by stereo lithography, one, solid and another with $500 \mu \mathrm{m}$ porosity. After the cellular activity tests, it is noticeable that there is more cellular activity in the porous scaffold than in the massive one. That is due to the increase of possible cell permeation area, since the massive scaffolds only allow tissue growth on its surface, while porous scaffolds allow the cells to enter the structure and proliferate there, allowing a more thorough tissue repair [61].

The following biofactors stand out amongst the ones most frequently used in bone tissue regeneration: angi- 
ogenic proteins, which regulate the proliferation of endothelial cells, and bone morphogenetic proteins, which stimulate the osteogenesis by differentiating osteoprogenitor cells and mesenchymal cells from osteoblasts. Hence, the scaffold must be porous enough to allow not only the transportation of these biofactors but also the vascularization that will provide blood supplies for the tissue regeneration and make it possible to remove the residual matter originated by the local cellular metabolism [35].

For the tissue formation to occur in an adequate way, it is necessary for the scaffolds to be extremely porous structures, with an average porosity of $40 \%-60 \%$. Scaffold macro porosity plays a critical role in the regeneration of damaged tissues, for it aims to allow cell penetration, which triggers the integration with the host tissue and increase the chances for key processes to take place (e.g. blood vessel in growth). The optimum pore size for scaffolds has been reported to be in the range between $100 \mu \mathrm{m}$ and $400 \mu \mathrm{m}$ [62] [63]. While pore sizes and pore interconnections in the range of hundreds of microns are relevant for cells to migrate and proliferate, pore sizes in a smaller range also play pivotal roles in tissue engineering [64] [65]. These pores are usually few microns in size and are involved mainly on the initial adsorption of proteins on the surface of the materials, and the increase in protein concentration may significantly affect cell fate for the better [66]-[68]. Besides the ability to adsorb proteins, these small sized pores are also known to allow the regulation of cell behavior, playing key roles in directing stem cell fate [69].

A recent work showed the effect of pore size $(100 \mu \mathrm{m}, 200 \mu \mathrm{m}, 350 \mu \mathrm{m}$ and $500 \mu \mathrm{m})$ of solid freeform fabrication polypropylene based scaffolds. The results showed optimum proliferation of pre-osteoblastic cell line MC3T3-E1 for scaffolds with $200 \mu \mathrm{m}$ and $350 \mu \mathrm{m}$ pore sizes, whereas the $500 \mu \mathrm{m}$ pore size scaffolds barely contained cells after 7 days [70]. This suggested that $500 \mu \mathrm{m}$ pore size was too big for cells to interact with [71].

Scaffolds can also be used for local delivery of drugs, and the advantages of these systems are the possibility of reducing the necessary dosage of the drug to obtain therapeutic efficacy and possible toxic effects, which creates a pattern of modified liberation [72]-[77]. Bose and collaborators (2013) used scaffolds obtained through inkjet printing, containing three different ceramic structures (brushite, monetite and hydroxyapatite), with the intention of allowing local release of vancomycin. It can be observed that with the use of scaffolds as release devices, it was possible to obtain the desired release pattern of the drug regardless of the ceramic structure [35].

As a way to avoid the problem of mechanical behavior versus bioactivity, the manufacturing of biodegradable polymer composites appeared, and with an addition of an inorganic phase to the polymeric matrix, it managed to achieve all the requirements of a scaffold [60] [78]. Serra and collaborators (2013) obtained PLA scaffolds through the solvent cast 3D printing, with the intention of observing the variation of two different factors. The first factor to be evaluated was related to the architecture of its layers, obtained through two different patterns: ORTH and DISPL. The difference between the specimens caused a variation in the final porous volume. The second factor was the addition of particles of G5 ceramic in the PLA matrix of the aforementioned architectures (ORTH-G5 and DISPL-G5). After the compression testing the authors were able to observe that scaffolds containing G5 ceramic showed better compressive modules than those that did not have the inorganic phase in both the analyzed architectures [79].

Due to the resemblance between calcium phosphates (CaPs) and minerals that exist in the bones, such as hydroxyapatite $\left[\mathrm{Ca}_{10}\left(\mathrm{PO}_{4}\right)_{6}(\mathrm{OH})_{2}-\mathrm{HA}\right]$, this group of ceramics is vastly used as the inorganic phase in the production of composites [54] [80]-[89]. Various authors have referred to the optimum content of HA particles of $10 \%$ - 30\% [90]-[93].

While revising the literature, it is possible to see that polymers such as poly (caprolactone) (PCL), poly (lactic acid) (PLA), poly (glycolic acid) (PGA), chitosan and its copolymers are the most frequently used as scaffold matrix [79]. PLA, for example, has been widely used in many applications such as screws, pins and plates for orthopedics [94], devices for controlled drug delivery [95]-[99] and scaffolds for bone regeneration [9] [100] [101]. The widespread use of these polymeric matrices is due to its biodegradability, which constitutes of an important factor for the synthetic scaffold to be replaced by new tissue, without leaving any residue. Not only the degradation time of each material is important, but the porosity of the scaffold also influences its biodegradability, since it is known to increase the ability of fluids to penetrate the structure and therefore enhances the degradation [35]. Ideally, the scaffold should degrade at the same time as new natural tissue is being formed [102] [103].

Therefore, the properties achieved by the scaffold vary between the maximum predicted by the chemistry of the material and the zero predicted by composites theories. That being said, it is necessary to think about a design for the scaffold which will balance the mechanical properties with the mass transportation properties and its biodegradation [35]. 


\section{Application of Nanotechnology in Tissue Regeneration}

The use of nanostructured materials in tissue engineering is inspired by the natural architecture of the bone, since, biologically speaking, the natural bone matrix is a nanocomposite formed by an inorganic phase of hydroxyapatite (HA) nanocrystals, dispersed in the organic phase, which consists of collagen nanofibers, with diameter varying between $5 \mathrm{~nm}$ - $50 \mathrm{~nm}$ (Figure 1) [104] [105]. That complex combination of an elastic matrix (elastic modulus $\mathrm{E}=1-2 \mathrm{GPa}$ and tensile strength $\mathrm{TS}=50$ - $1000 \mathrm{MPa}$ ) with a strong and breakable mineral phase $(\mathrm{E}=130 \mathrm{GPa}$, TS = $100 \mathrm{MPa}$ ) leads to a composite material with ductile characteristics and good fracture resistance [106]. Hence, the creation of a nanocomposite can adequately mimic the properties presented by natural bone and combine the advantages of both components, achieving bigger properties than those presented by its individual components [41] [107]. Then, the use of nanocomposites proved advantageous because there still isn't a single material that is biocompatible, biodegradable and has good mechanical properties to replace the bone, as Figure 2 shows [106].

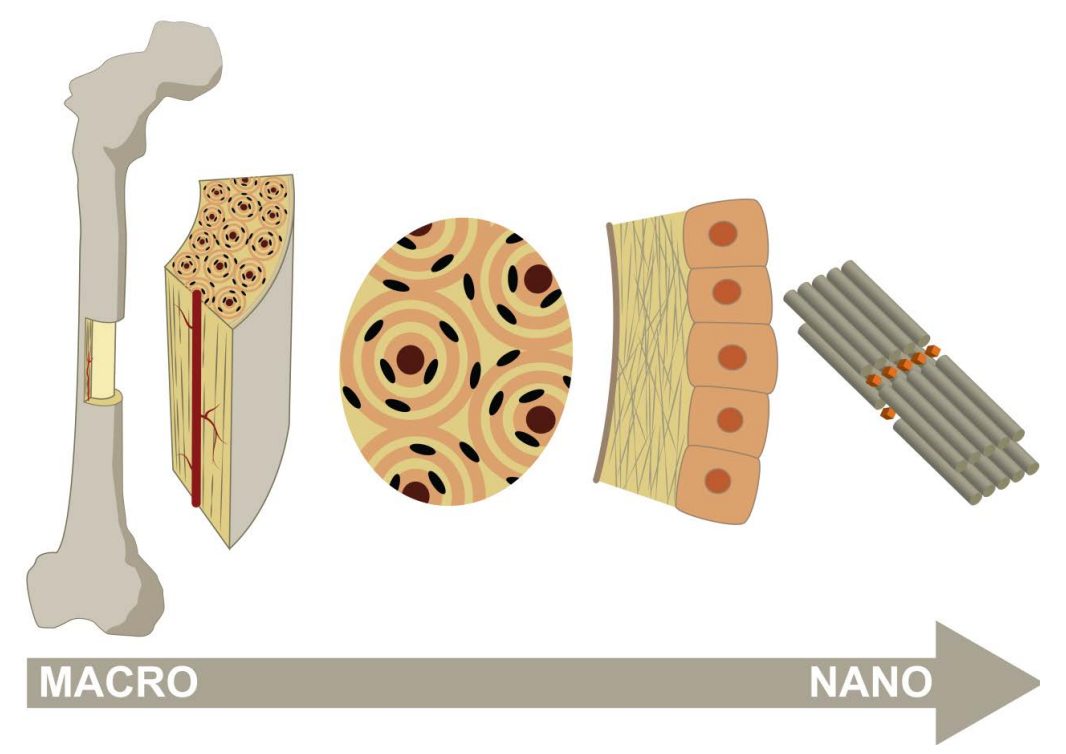

Figure 1. Hierarchical organization of the components of bone tissue, from the macro scale to the nanometric scale.

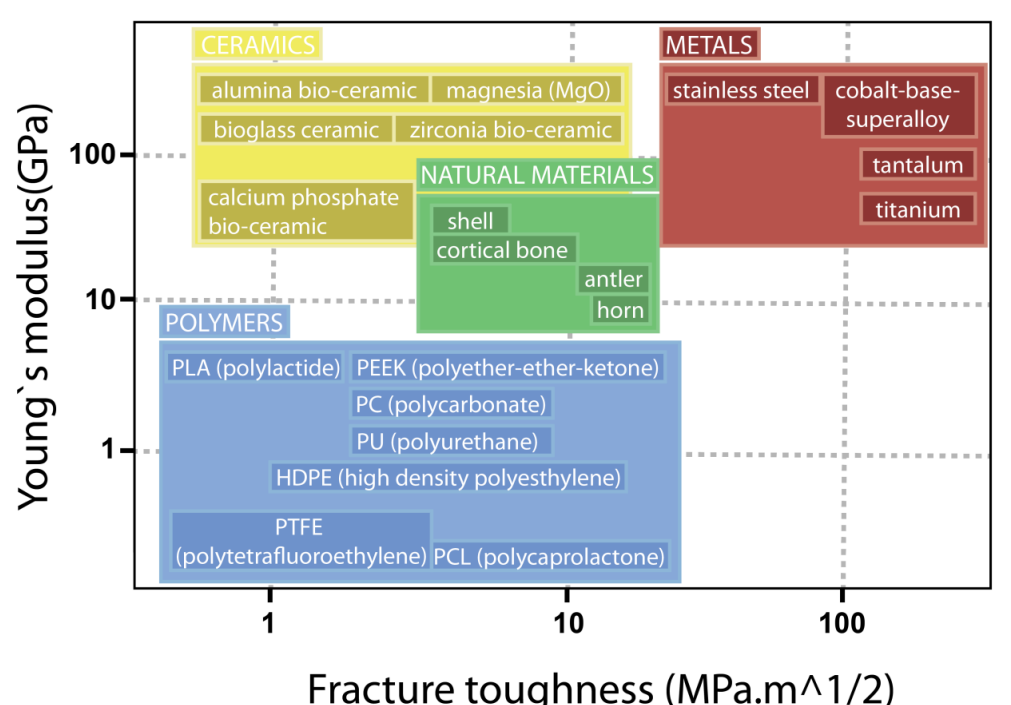

Figure 2. Mechanical properties of the natural materials compared to those of the materials used in the biomedical field. 
One of the most important criteria in the development of an orthopaedic implant is the osseointegration between the synthetic material and the bone tissue. In that aspect, there are many studies that demonstrate that nanostructured materials promote protein interactions favorable to bone growth due to its surface properties. That happens because when a material is reduced to the nanometric scale there is a significant increase in the contact area, which increases its physical-chemical properties, compared to those of the macrometric material [108] [109].

Therefore, it is very advantageous to use nanotechnology, since it increases the function, adherence and proliferation of the bone cells, due to its favorable surface properties [109] [110]. Since the nanomaterial has a bioactive surface that mimes the surface of the natural bone, it promotes a better absorbency of proteins and biofactors, encouraging a better bone formation than any conventional material could do [111]-[114]. Besides, nanostructuring often enhances the mechanical strength of composite materials [112] [115]-[117].

In 2011, the European Commission defined nanomaterial as a natural material, accidental or manufactured, that contains particles, either alone or aggregated, that have at least between $1 \mathrm{~nm}$ and $100 \mathrm{~nm}$ in dimension. However, there are other definitions in literature that amplify the definition of the nano prefix to include structures that exceed $100 \mathrm{~nm}$, including, then, a great variety of structures [41].

Amongst known nanomaterials, there are nanoparticles, nanotubes, nanocrystals, nanofibers and nanowires that can be integrated in tissue engineering to produce bioactive scaffolds due to their unique surface properties [118] [119].

For that reason, there are many nanomanufacturing technologies, both top-down and bottom-up, such as, for instance: electro spinning, phase separation, self-assembly, casting of a nanostructured film, chemical vapor deposition, to mention only a few of them [109]. Furthermore, due to the high interfacial area of nanoparticles, mechanical enhancement is observed for very low loading fractions (up to $10 \mathrm{wt} \%$ ) [108].

Nanotechnology is partially responsible for the great progress in the biomedical field in the past few years, and, consequently, nanomaterials are now being industrially manufactured in mass and some products are being sold already [120] [121]. However, it is necessary to be cautious because there are currently only a few studies regarding the toxicity of nanomaterials. It is necessary to acquire more information regarding: the nanoparticles derived from the biodegradation of scaffolds, their interaction with in vivo biomolecules and probable agglomeration, their capture by macrophages, their entry in endothelial cells and the resulting toxic effects [109].

\section{3D Printing}

3D printing is a term that refers to many techniques used to create a $3 \mathrm{D}$ object through a rendered computer model [79]. It is a fast prototyping technology that is considered revolutionary and differs from the existing technologies for the fact that it is an additive manufacturing method. Unlike subtractive manufacturing technologies, which are based around the removal of excessive and superfluous material until the desired object is acquired, 3D printing is an additive manufacturing technique [122]-[126] that builds the objects piece by piece, using only the material that will become part of the object and avoiding loss of material in the process [127] [128]. Besides, 95\% to $98 \%$ of the excess of 3D printing, like annex structures to support the printed piece, can be recycled, processed and reutilized in a new printed object [129].

The technology of the 3D printer is tied to that of computer-aided designs-CADs) softwares, where the design of the object is made. The geometry of the object can be achieved through modelling softwares, mathematical equations or scanning [130]. The sentence "everything that can be drawn can be printed" is considered the basis of 3D printing, but actually, it is a utopian idea that shall still be achieved. Currently, to be printed, an object needs to be completely solid. Once modelled, the object is "sliced" by a specific program called slicer, which means to divide the object in two-dimensional slices to determine a way to print it [127] [129] [131] [132].

What initially caused the development of the 3D printing was the necessity that the inventor of stereo lithography, Charles W. Hull, had for a kind of commercial fast prototyping, because of the great need to test and manufacture models in a faster way, without the need to store them. In that aspect, 3D printing supplied that demand, which brought advantages for big companies and small businesspersons, researchers and scientists alike [127]. Hence, the combination of flexibility, quickness and low cost is what makes 3D printing a disruptive technology.

Nowadays this printing technology is accessible to a large part of the world population, with printers costing between US\$500 and US\$2000 [127]. The process of 3D printing is highly automated and only requires human 
labor during its pre-processing and post-processing; this ease in the process propels its growth and its expansion [133]. On the other hand, the high availability and the easy access to 3D designs in the internet makes it difficult to protect the intellectual property of the user; since the design of the object is described and made available online, it is easy for it to be copied, plagiarized and resold [129].

3D printing is ideal to the manufacturing of spare parts, since, when using conventional techniques, like injection molding, spare parts need to be manufactured in large quantities and at once. When faced with an uncertain demand and with the intention of reducing storage costs, 3D printing becomes an essential tool, because it allows the manufacturing of objects only when necessary, which optimizes the production and eliminates costs [129]. Through this perspective, Gebler and collaborators (2014) have made a prediction for the world in 2025 and determined that the cost reduction brought by 3D printing would be somewhere between US\$170 billion and US\$593 billion [133].

Another advantage of $3 \mathrm{D}$ printing is the large variety of materials that can be used. Polymers are used, amongst which the copolymer of acrylonitrile butadiene styrene (ABS) and poly (lactic acid) (PLA) stand out. However, there still is the possibility to use other materials such as epoxy resin, nylons, waxes, metals (like titanium and silver), chocolate and body tissues like cartilage [127]. Material selection, which is a vital part of the process, is governed by the printer type used and the requirements of the final product [134].

Due to the many possibilities of its usage and wide variety of materials that can be used [135] [136], 3D printing emerged from automotive, microelectronics and aerospace fields into the biomedical field. That way, the 3D printing technique has obtained a widespread diversity of applications for biological use, which include: the study of organ bioprinting for transplants [137]; the production of prosthetics with a lessened final cost; the production of surgical tools [138]; and the production of bioscaffolds, that work as analogues to the damaged tissue targeting tissue regeneration [139] [140]. In fact, several 3D printing techniques have already been used to design and manufacture scaffolds for medical applications, including fused deposition modeling (FDM), stereo lithography (SLA), Inkjet printing, and selective laser sintering (SLS) [141]-[143].

That application is possible because the 3D printing technique allows the overcoming of limitations regarding scaffold design and processing posed by conventional techniques [144] [145]. That way, the evolution that bioprinting can bring to the scaffolds field is huge because it makes it possible to have more control over the architecture, allowing the manufacturing of microstructures that mimic the porosity and interconnectivity between the pores in the human body [139].

Kim and collaborators (1998) were pioneers at 3D printing PLGA scaffolds, managing to obtain $800 \mu \mathrm{m}$ pores. Later, the process was combined with a salt leaching technique in order to obtain smaller pores (in the range of $40 \mu \mathrm{m}-150 \mu \mathrm{m}$ ) [146]. Many studies followed his cue, inspired by the control over the porosity the 3D printing offers [21] [147] [148]. Since the design of the scaffold is made by a computer, its structure can be thoroughly controlled, modified, tested and reproduced. The ease of creating and modifying a design was the main appeal to the tissue engineering field, considering the properties of the final scaffold, including cellular adherence, are closely related to its architecture [21].

In addition, there is the possibility to print cells, DNA, and other bioactive components simultaneously with the printing of the polymer support matrix, layer by layer, and that would make the final product achieve a higher cellular density in the matrix than other techniques of cellular sedimentation that always happen after the polymeric scaffold is manufactured [62] [149] [150]. The first attempts were made in 2D by Odde et al. (1999), who printed spinal cord cells on glass tray layered with culture medium using laser guided printing [151]. In 2003 Boland et al. modified a commercial HP inkjet printer and using print heads from HP and Epson managed to print protein and mammalian cells onto alginate culture material. In order to print living cells the inkjet heads had to be modified to be able to eject droplets larger than $100 \mu \mathrm{m}$ [152]. Saunders et al. (2004) managed to print chondrocytes, osteoblasts and fibroblasts in a cell suspension with a 30 - $60 \mu \mathrm{m}$ nozzle [153].

However, the available techniques for 3D printing focused on scaffolds, but would not allow cell printing. Methods such as laser sintering, fused deposition modelling and 3D printing can only allow the printing of synthetic scaffolds, but cells cannot be simultaneously added to the printed constructs because they are not able to survive the printing method due to high pressure, temperature or the use of cytotoxic materials [154].

Matrix material for tissue printing, often described as bioink, is central to this process and should provide suitable cues and signals for cellular function and tissue formation [155]. Various individual extracellular matrix (ECM) components like collagen and fibrin have been used as bioinks [156] [157]. Recent studies have indicated that a tissue-specific ECM may direct cellular responses to promote constructive tissue regeneration [109]. 
Cellular responses and functions dramatically improve when decellularized adipose tissue (DAT) is used for fabrication of scaffolds [158]. Decellularization conserves the natural constitution of ECM, but removes cellular and antigenic components that can provoke immune responses [159] [160]. Besides, it is well accepted that cells grown in tissue-mimicking 3D conditions display phenotypes in specific ways that are more close to in vivo situations than those cultured on 2D substratum [161] [162]. That way, 3D printed tissues can be used for research and treatment of a great variety of diseases; cancer being one of them [163].

Labs everywhere are printing prototypic organs including heart valves, ears, artificial bone, joints, menisci, vascular tubes and skin grafts. The structural and compositional complexity associated with many types of tissue greatly complicates both the programming and the printing [164]. Even the tremendous challenge of achieving viable vascularized tissue constructs is potentially enabled by the additive processing approach [165] [166]. Another advantage of 3D printing in the biomedical field is that, unlike other techniques, it is possible to obtain a heterogeneous material with the application of different materials that can be deposited in specific positions of the final structure [140].

\section{Techniques for Scaffold 3D Printing}

Hopkinson and collaborators (2006) described 18 types of 3D printing that can be divided according to the physical state of the printed material (solid or liquid), or according to the method applied to fuse the matter in a molecular level (thermal, UV radiation, laser, amongst others) [167], but only the five most known and most widely used in the biomedical field (selective laser sintering, stereo lithography, fused filament fabrication, solvent casting and inkjet) will be described in this paper.

\subsection{Selective Laser Sintering}

As the name states, this technique uses a laser to sinter the material that is in powder form. The laser irradiates determined areas, following a predetermined path, and heats up the material close to its fusion temperature, creating and uniting the layers of the object being made (Figure 3). After each transversal section is designed through the laser irradiation on the powder bed, the table moves in the z-axis and a new layer of material is applied over it. Since the polymer powders are approximately $30 \mathrm{~m} \mathrm{-} 90 \mathrm{~m}$ in dimension, this means only about 2 4 particles represent a layer thickness. That way, the process repeats itself until the piece is finished [127] [168]-[170]. After the part is completed, the entire building chamber is cooled slowly to maximize polymer
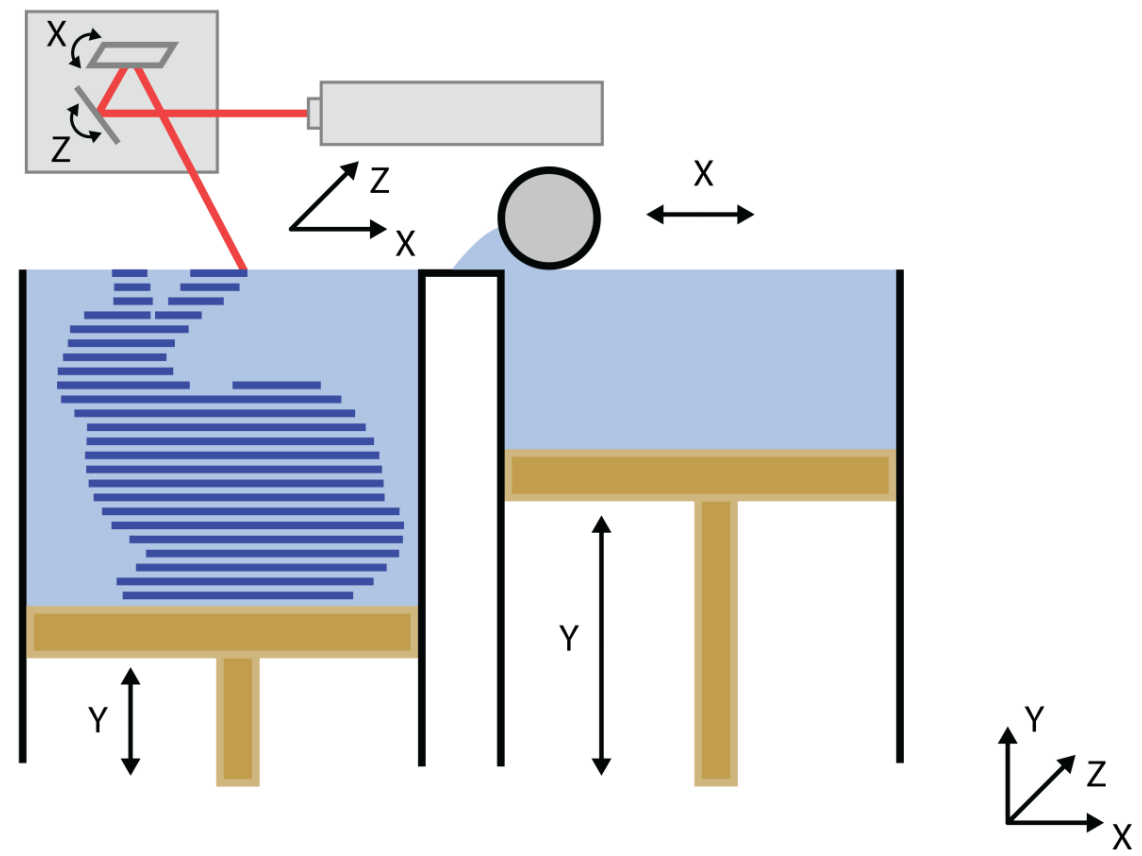

Figure 3. Schematics of the selective laser sintering method. 
crystallization to provide added strength as well as to reduce stress development and improve dimensional accuracy, which can be improved further by incorporation of shrinkage modeling into the initial part design [171].

The use of a laser makes sintering one of the techniques with a higher definition, allowing for the manufacturing of geometrically complex pieces [127]. Additionally, this technique allows for a larger variety of materials, so long as they are in powder form, that way glass, metal and ceramic can be used and adapted to the scaffold production. Semi-crystalline polymers are primarily used with the intrinsic selection criteria ideally including a broad process temperature window between polymer melting upon heating and recrystallization upon cooling, a narrow melt transition, and a high melting enthalpy to minimize unwanted sintering associated with thermal conductivity [172]. This technique also presents better productivity, since there is no need to build support structures, because the powder is both the reagent and the support for the manufactured material [173].

A range of fillers, such as silica, aluminum, carbon fiber and glass, can also be incorporated into the powdered polymer to further modify the appearance and properties of the printed parts. Silica can be added separately to polymer powders to improve flow properties. Achieving uniform distribution of filler in a mixed powder system where differences in particle size and density are involved makes this nontrivial [128].

\subsection{Stereo Lithography}

It was the first developed and patented 3D printing technique in 1986, by Hull [174], and it is still the most accurate of the techniques. Due to its pioneering as a printing technique, the first commercial 3D printer was stereo lithographic [61]. Therefore, this technique has been widely used in bioengineering and extensively reviewed [175] [176]. The principle of stereo lithography is based upon photo polymerization of vinyl monomers, which is activated by the decomposition of a photo initiator into free radicals when exposed to UV radiation or visible light [61] [177]-[179].

UV radiation scans and solidifies the regions corresponding to the transversal sections of the final objects, creating the object one micro layer at a time (Figure 4). After a layer is irradiated and cured with UV radiation, the elevator goes down the length of a layer (approximately between $0.05 \mathrm{~mm}$ and $15 \mathrm{~mm}$ ), and the process is

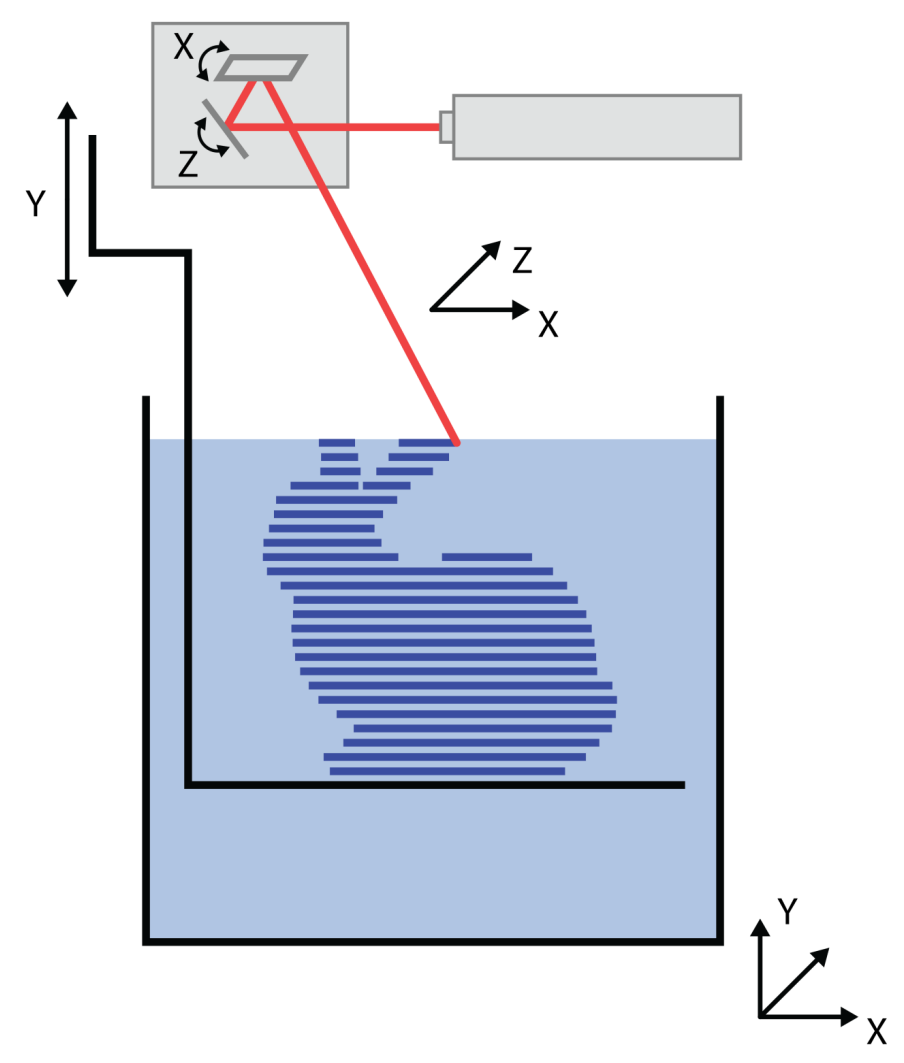

Figure 4. Schematics of the stereo lithography method. 
repeated over a new liquid layer [130].

After the process ends, the object is washed to remove the excess of resin. The object obtained does not present a complete conversion of the reactive groups and it can be post-cured with UV to increase the structures mechanical properties [130]. This technique is widely used to manufacture polymeric scaffolds. However, most photo initiators are insoluble in water and need to be dissolved in organic solvents, which makes them toxic for cells. That is added to the risk of breaking the DNA's double helix with UV radiation [180]. For that, the printing of cells along with the scaffold is not recommended, and so the cells are sedimented in the scaffold after its manufacturing [61].

To avoid these problems and print the cells simultaneously, it is necessary: i) to use visible light, ii) that the photo initiator is sensitive to visible light, efficient and soluble in water, but not cytotoxic, iii) to achieve a uniform cells suspension in the monomer/initiator solution, iv) that the material of the scaffold is hydrophilic and not cytotoxic, to maintain the cellular viability after sedimentation. Hydrogels are widely used because of their ability to retain water and because their properties mimic those of the living tissue [106].

This method is one of the most promising for scaffold manufacturing because it is possible to print objects with accuracy of up to $20 \mu \mathrm{m}$, while the other techniques allow accuracy of up to $50 \mu \mathrm{m}-200 \mu \mathrm{m}$. However, it is a technique that not does allow a wide variety of materials, nor the use of more than one resin at the same time [130].

Surface-patterned exposure from digital light projection (DLP) sources allows any selected portion of the entire $\mathrm{x} / \mathrm{y}$ workspace to be exposed simultaneously instead of dynamic writing with a condensed laser beam [181]. Even though high laser scanning velocities are employed in the SLA approach, the ability to simultaneously photo cure all portions of a given slice with DLP significantly speeds cycle times between layers [176]. The SLA or DLP techniques can be used with a wide variety of monomers and resin systems. Ideally, the monomers (typically comonomers and reactive oligomers) used in photo polymerization-based part printing should be of relatively low to modest overall viscosity (viscosities either too low or too high introduce problems), capable of rapid polymerization and yield cross linked polymers with properties suited to the demands imposed by the target application. Just as in the UV-curable coatings industry, this means that acrylates and epoxy monomers are most commonly encountered as photo-based printing materials although vinyl ether-functionalized monomers and other monomer types are used as well. Also related to the UV coatings industry, relatively high photo initiator concentrations (often up to $3 \mathrm{wt} \%$ - 5wt\%) are used to achieve fast polymerization and limited depth of cure [128].

\subsection{Fused Filament Fabrication}

In this process, the material is fused, extruded and deposited on a table, layer by layer. The extrusion head and the table move in the $\mathrm{x}, \mathrm{y}$, and $\mathrm{z}$ axes, allowing the material to be deposited in any position (Figure 5). The material cools down, and it solidifies by itself, as it is extruded, so there is no need to use a light source [182].

The use of filaments reduces the residence time in the heating compartment, which allows fast and continuous deposition, something essential to commercial production [33].This technique has limitations regarding the materials that can be used, since only a few polymers have the thermal and rheological properties to be processed. PLA and ABS are the most commonly used [183].

Recent work has further expanded the materials palette to include other polymer blends, and even recycled commodity polymer stocks can be considered for use [184]. It is possible that orientation of polymeric chains happens during the fused filament's extrusion and, in that case, the resulting material will have unique structural properties that exceed those of an object manufactured with the same material but with a different technique [183]. It is possible, beyond controlling the architecture of the scaffold through the design, to change parameters such as deposition speed; at a higher speed, the filament will have a smaller diameter and be more porous. That control is important because, as previously stated, the porosity influences the scaffold properties directly, such as elastic modulus and degradation kinetic [185].

\subsection{Solvent Casting 3D Printing}

This technique was developed as a low-cost strategy to overcome the limitations of the fused filament fabrication technique. It consists of the additive deposition of layers of material directly from a solution made by a volatile solvent (Figure 6). For that reason, it presents gigantic potential in the microelectronics and 


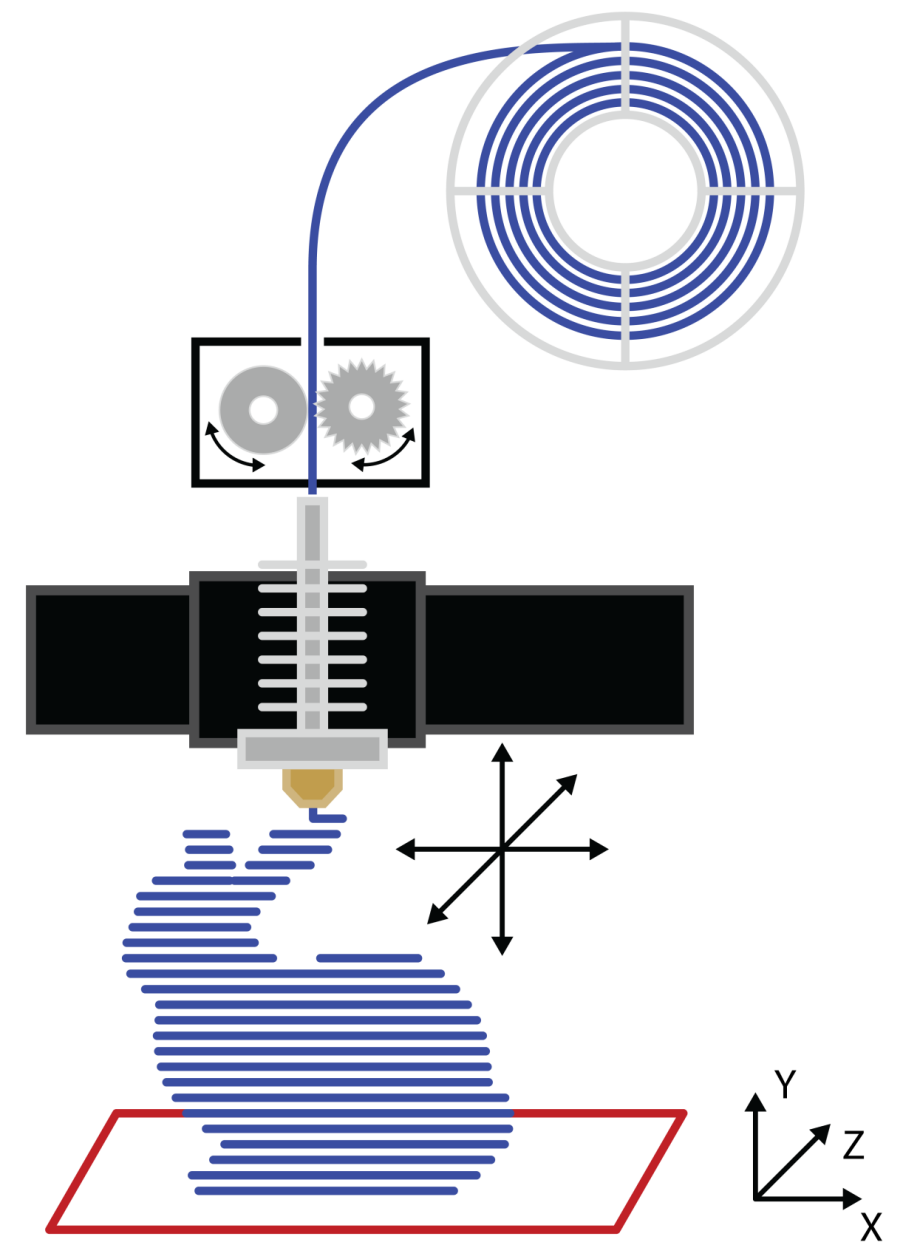

Figure 5. Schematics of the fused deposition modeling method.

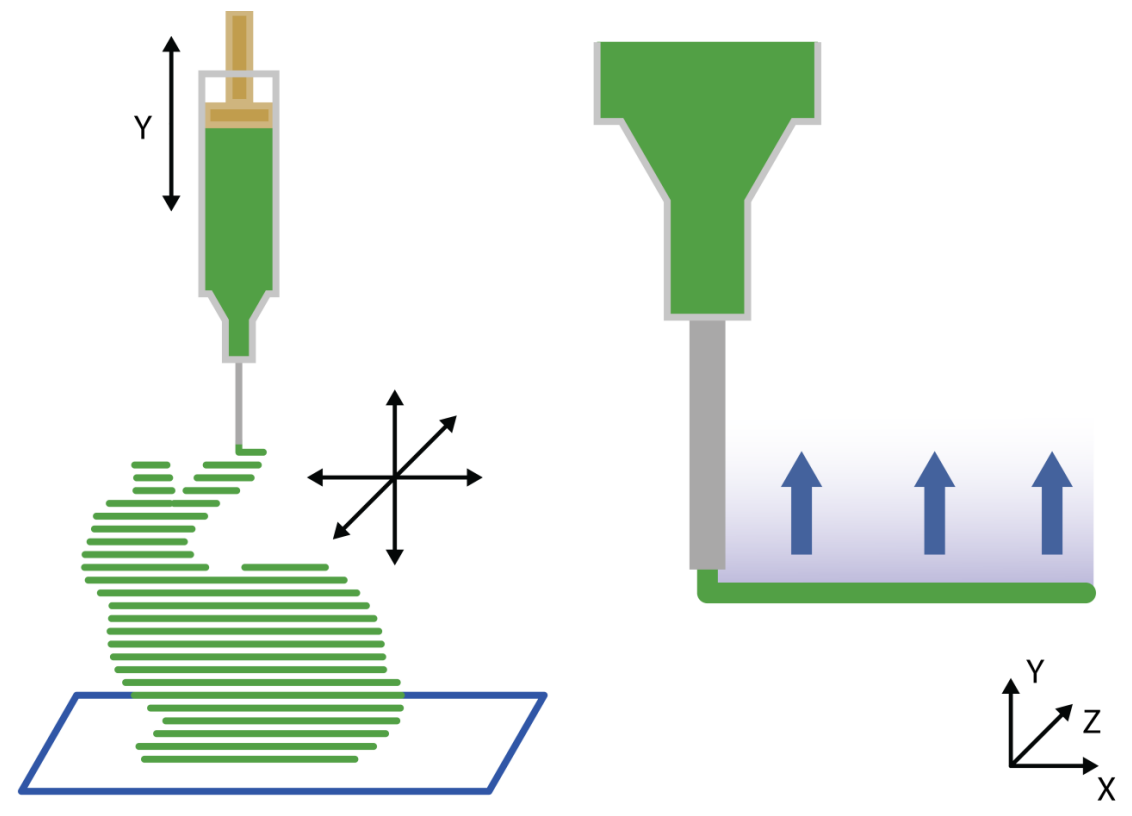

Figure 6. Schematics of the solvent cast 3D printing method. 
biomedical engineering fields, since it allows the direct manufacturing of versatile composites and nanocomposites at a low cost [183].

The solvent needs to be volatile in order to evaporate during deposition and, consequently, increase the viscosity of the material and the quick formation of a rigid 3D microstructure [79]. The viscosity of the solution is an important parameter since it is inversely related to the fluidity; if it is too viscous, there is a risk of clogging up the printing head, but if it is not viscous enough the solvent will evaporate too slowly and the 3D structure will be under the risk of collapsing. Hence it is important to characterize the rheological behavior of the solution at different shear rates to make sure that the viscosity will never surpass these extreme values, compromising the technique [186]. Another important thing to keep in mind with this technique is the homogenous dispersion of charge in the polymer; if there is an agglomeration, the nano effect will be lost and it can clog up the printing head, impairing the process [183]. Serra and collaborators (2013) have produced PLA/PEG scaffolds as polymeric matrix and particles of G5 ceramic as the inorganic phase using this technique. PEG was used as plasticizer to lower the $\mathrm{Tg}$ of the material and to make its processing easier. The resulting scaffolds had thinner filaments than those in scaffolds obtained through different techniques and that was mostly due to the viscosity of the solution used and the evaporation of the solvent, which happens after the deposition of the filaments. That effect is desirable, because it generates higher resolution scaffolds, increasing its contact area and interaction with the biological medium. The scaffolds produced through the fused filament fabrication technique do not show significant amounts of deposed filament thinning [79].

\subsection{Inkjet}

It is the manufacturing of 3D objects through the deposition of a liquid binder in a layer of powder (Figure 7) [187] [188]. As most materials are in solid or liquid state, this technique allows a large variety of materials to be used, which is already a big advantage compared to other additive manufacturing techniques [189]-[191]. After printing a layer, it must be heated up to dry the binder and avoid it spilling between layers. This process is repeated, layer by layer, until the object is complete. Even so there can be some residue left, which can be damaging, especially to the area of the biomaterials [35] [194]. To print polymeric scaffolds, the binder is a solvent, the polymer is dissolved, but as soon as the solvent evaporates, the polymer reprecipitates to form solid structures [192] [193].
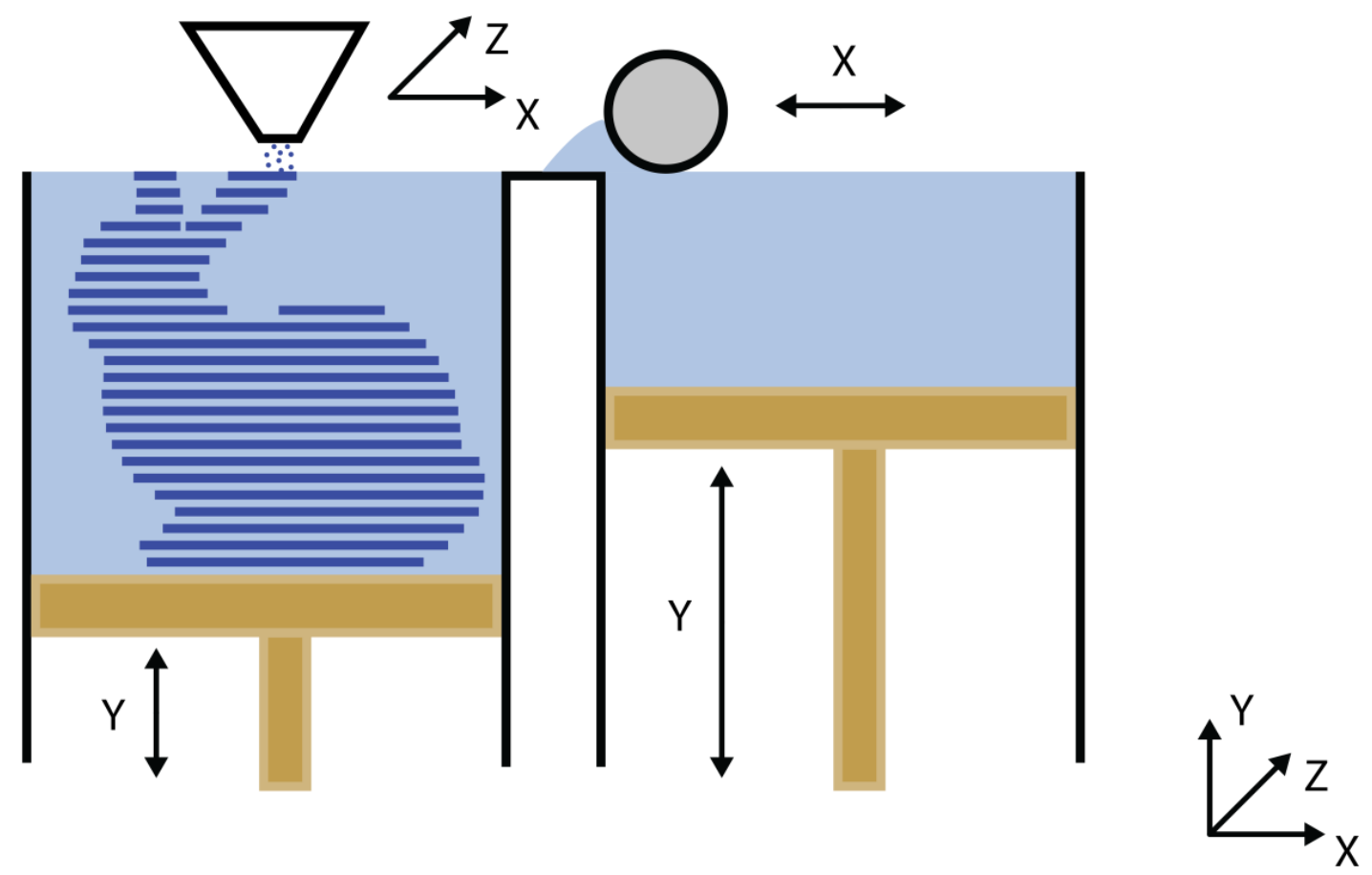

Figure 7. Schematics of the inkjet method. 
According to Asadi-Eydivand and collaborators (2015), despite the massive potential of polymeric scaffolds with micro sized pores, most scaffolds successfully manufactured by inkjet have pores bigger than $500 \mu \mathrm{m}$ [194]. Other than pore size, another limiting factor is the need to use an organic solvent in the solubilisation of the polymers that can eventually damage the printing head [165], and can leave residues in the printed object [54]. To overcome this problem, Lam and collaborators (2002) have created corn starch polymeric scaffolds, using distilled water as the binder [21].

A possible way to avoid the first problem is by printing molds with cavities in which the final material can be poured, which is called indirect 3D printing. Afterwards, the mold must be removed, dissolved in a material that will not dissolve the scaffold's material [192] [195]-[198]. Deisinger and collaborators (2007) made a comparison between direct and indirect 3D printing methods by fabricating hydroxyapatite scaffolds. Based on the results, the pore size and strut geometries in the indirect method were more achievable compared with the direct technique [199]. By the end of the printing process, another stage is needed, to remove the excess dust in the object, using compressed air [54]. The term "3D printability" was first defined by Butscher and collaborators (2012) as "powder characteristics essential for the 3DP process" and it intrinsically depend on: (1) powder topology, including particle size, particle size distribution, morphology and specific surface area and (2) material reactivity with the binder [123]. Among the powder topological characteristics, particle size has been demonstrated as the dominant factor in determining the quality of printed products [200]. Lu and collaborators (2009) has suggested that higher strength for 3DP constructs prior to any hardening post-process (i.e. green strength) can be achieved using fine powder $(\mathrm{b} 20 \mu \mathrm{m})$, whereas other studies found fine powder caused issues with spreading during the 3DP process [200] [201]. These contradictory results indicate lack of understanding of this emerging manufacturing technology, especially on the fundamental principles of how the binder droplets interact with the powder during the 3DP process [202].

\section{Closing Remarks}

The importance of porosity in the study of polymeric scaffolds used in bone tissue engineering is fundamental, since it directly changes its permeability to nutrients and biofactors, its mechanical properties and its biodegradation kinetic. For this reason, the advent of 3D printing allows us to overcome limitations of traditional scaffolds manufacturing techniques, because the structure is built layer by layer, according to a predetermined computer model, which provides better control of the scaffold's architecture and geometry. Hence, it is possible to vary, with a certain amount of accuracy, the porosity degree, the size of the pores and their interconnectivity, aiming to achieve the ideal balance between mechanical support and mass transportation and to maximize the scaffolds function of guiding and stimulating tissue repair.

However, since 3D printing technology is fairly recent and there is no well-established knowledge about it in the medical field, it is necessary to research more about the subject and to explore the repercussion of the use of different printing techniques, because there are many factors that influence the final properties of the printed structure, such as the chosen material, the resolution of each technique, the time it takes to print and speed of the printing, and the computer model. Besides that, it is also necessary to evaluate the applicability of the nanomaterials in the 3D printed scaffolds, with the intent of obtaining synergetic results in the mechanical and biological properties.

\section{References}

[1] Mano, J.F., Sousa, R.A., Boesel, L.F., Neves, N.M. and Reis, R.L. (2004) Bioinert, Biodegradable and Inject Able Polymeric Matrix Composites for Hard Tissue Replacement: State of the Art and Recent Developments. Composites Science and Technology, 64, 789-817. http://dx.doi.org/10.1016/j.compscitech.2003.09.001

[2] Patrício, T., Domingos, M., Gloria, A. and Bártolo, P. (2013) Characterisation of PCL and PCL/PLA Scaffolds for Tissue Engineering. Procedia CIRP, 5, 110-114. http://dx.doi.org/10.1016/j.procir.2013.01.022

[3] Melchels, F.P.W., Domingos, M.A.N., Klein, T.J., Malda, J., Bartolo, P.J. and Hutmacher, D.W. (2012) Additive Manufacturing of Tissues and Organs. Progress in Polymer Science, 37, 1079-1104. http://dx.doi.org/10.1016/j.progpolymsci.2011.11.007

[4] Patterson, J., Martino, M.M. and Hubbell, J.A. (2010) Biomimetic Materials in Tissue Engineering. Materials Today, 13, 14-22. http://dx.doi.org/10.1016/S1369-7021(10)70013-4

[5] Huang, R., Zhu, X., Tu, H. and Wan, A. (2014) The Crystallization Behavior of Porous Poly(Lactic Acid) Prepared by 
Modified Solvent Casting/Particulate Leaching Technique for Potential Use of Tissue Engineering Scaffold. Materials Letters, 136, 126-129. http://dx.doi.org/10.1016/j.matlet.2014.08.044

[6] Sin, D., Miao, X., Liu, G., Wei, F., Chadwick, G., Yan, C., et al. (2010) Polyurethane (PU) Scaffolds Prepared by Solvent Casting/Particulate Leaching (SCPL) Combined with Centrifugation. Materials Science and Engineering: C, 30, 78-85. http://dx.doi.org/10.1016/j.msec.2009.09.002

[7] Mozafari, M., Moztarzadeh, F., Rabiee, M., Azami, M., Maleknia, S., Tahriri, M., et al. (2010) Development of Macroporous Nanocomposite Scaffolds of Gelatin/Bioactive Glass Prepared through Layer Solvent Casting Combined with Lamination Technique for Bone Tissue Engineering. Ceramics International, 36, 2431-2439. http://dx.doi.org/10.1016/j.ceramint.2010.07.010

[8] Nam, Y.S., Yoon, J.J. and Park, T.G. (1999) A Novel Fabrication Method of Macroporous Biodegradable Polymer Scaffolds Using Gas Foaming Salt as a Porogen Additive. Journal of Biomedical Materials Research Part A, 53, 1-7. http://dx.doi.org/10.1002/(SICI)1097-4636(2000)53:1<1::AID-JBM1>3.0.CO;2-R

[9] Salerno, A., Fernández-Gutiérrez, M., del Barrio, J.S.R. and Domingo, C. (2015) Bio-Safe Fabrication of PLA Scaffolds for Bone Tissue Engineering by Combining Phase Separation, Porogen Leaching and $\mathrm{scCO}_{2}$ Drying. The Journal of Supercritical Fluids, 97, 238-246. http://dx.doi.org/10.1016/j.supflu.2014.10.029

[10] Zhu, X.H., Lee, L.Y., Sheng, J., Jackson, H., Tong, Y.W. and Wang, C. (2008) Characterization of Porous Poly(D, L-Lactic-co-Glycolic Acid) Sponges Fabricated by Supercritical $\mathrm{CO}_{2}$ Gas-Foaming Method as a Scaffold for ThreeDimensional Growth of Hep3B Cells. Biotechnology and Bioengineering, 100, 998-1009. http://dx.doi.org/10.1002/bit.21824

[11] Nam, Y.S. and Park, T.G. (1999) Porous Biodegradable Polymeric Scaffolds Prepared by Thermally Induced Phase Separation. Journal of Biomedical Materials Research Part A, 47, 8-17. http://dx.doi.org/10.1002/(SICI)1097-4636(199910)47:1<8::AID-JBM2>3.0.CO;2-L

[12] Fouad, H., Elsarnagawy, T., Almajhdi, F.N. and Khalil, K.A. (2013) Preparation and in Vitro Thermo-Mechanical Characterization of Electrospun PLGA Nanofibers for Soft and Hard Tissue Replacement. International Journal of Electrochemical Science, 8, 2293-2304.

[13] Wang, C. and Wang, M. (2014) Electrospun Multifunctional Tissue Engineering Scaffolds. Frontiers of Materials Science, 8, 3-19. http://dx.doi.org/10.1007/s11706-014-0241-0

[14] Castilho, M., Pires, I., Gouveia, B. and Rodrigues, J. (2011) Structural Evaluation of Scaffolds Prototypes Produced by Three-Dimensional Printing. The International Journal of Advanced Manufacturing Technology, 56, 561-569. http://dx.doi.org/10.1007/s00170-011-3219-4

[15] Lee, E., Koh, Y., Yoon, B., Kim, H. and Kim, H. (2007) Highly Porous Hydroxyapatite Bioceramics with Interconnected Pore Channels Using Camphene-Based Freeze Casting. Materials Letters, 61, 2270-2273. http://dx.doi.org/10.1016/j.matlet.2006.08.065

[16] Monmaturapoj, N. and Yatongchai, C. (2011) Influence of Preparation Method on Hydroxyapatite Porous Scaffolds. Bulletin of Materials Science, 34, 1733-1737. http://dx.doi.org/10.1007/s12034-011-0384-x

[17] Scalera, F., Gervaso, F., Sanosh, K.P., Sannino, A. and Licciulli, A. (2013) Influence of the Calcination Temperature on Morphological and Mechanical Properties of Highly Porous Hydroxyapatite Scaffolds. Ceramics International, 39, 4839-4846. http://dx.doi.org/10.1016/j.ceramint.2012.11.076

[18] Swain, S.K., Bhattacharyya, S. and Sarkar, D. (2011) Preparation of Porous Scaffold from Hydroxyapatite Powders. Materials Science and Engineering: C, 31, 1240-1244. http://dx.doi.org/10.1016/j.msec.2010.11.014

[19] Leong, K.F., Cheah, C.M. and Chua, C.K. (2003) Solid Freeform Fabrication of Three-Dimensional Scaffolds for Engineering Replacement Tissues and Organs. Biomaterials, 24, 2363-2378. http://dx.doi.org/10.1016/S0142-9612(03)00030-9

[20] Ryan, G.E., Pandit, A.S. and Apatsidis, D.P. (2008) Biomaterials Porous Titanium Scaffolds Fabricated Using a Rapid Prototyping and Powder Metallurgy Technique. Biomaterials, 29, 3625-3635. http://dx.doi.org/10.1016/j.biomaterials.2008.05.032

[21] Lam, C.X.F., Mo, X.M., Teoh, S.H. and Hutmacher, D.W. (2002) Scaffold Development Using 3D Printing with a Starch-Based Polymer. Materials Science and Engineering: C, 20, 49-56. http://dx.doi.org/10.1016/S0928-4931(02)00012-7

[22] Anselme, K. (2000) Osteoblast Adhesion on Biomaterials. Biomaterials, 21, 667-681. http://dx.doi.org/10.1016/S0142-9612(99)00242-2

[23] Curran, J.M., Chen, R. and Hunt, J.A. (2006) The Guidance of Human Mesenchymal Stem Cell Differentiation in Vitro by Controlled Modifications to the Cell Substrate. Biomaterials, 27, 4783-4793.

http://dx.doi.org/10.1016/j.biomaterials.2006.05.001

[24] Glass-Brudzinski, J., Perizzolo, D. and Brunette, D.M. (2002) Effects of Substratum Surface Topography on the Or- 
ganization of Cells and Collagen Fibers in Collagen Gel Cultures. Journal of Biomedical Materials Research Part A, 61, 608-618. http://dx.doi.org/10.1002/jbm.10243

[25] Kommareddy, K.P., Lange, C., Rumpler, M., Dunlop, J.W.C., Manjubala, I., Cui, J., et al. (2015) Two Stages in Three-Dimensional in Vitro Growth of Tissue Generated by Osteoblastlike Cells. Biointerphases, 5, 45-52.

[26] Rumpler, M., Woesz, A., Dunlop, J.W.C., Van Dongen, J.T. and Fratzl, P. (2008) The Effect of Geometry on ThreeDimensional Tissue Growth. Journal of the Royal Society Interface, 5, 1173-1180. http://dx.doi.org/10.1098/rsif.2008.0064

[27] Hollister, S.J. (2005) Porous Scaffold Design for Tissue Engineering. Nature Materials, 4, 518-524. http://dx.doi.org/10.1038/nmat1421

[28] Leukers, B., Gulkan, H., Irsen, S.H., Milz, S., Tille, C., Schieker, M., et al. (2005) Hydroxyapatite Scaffolds for Bone Tissue Engineering Made by 3D Printing. Journal of Materials Science: Materials in Medicine, 16, 1121-1124. http://dx.doi.org/10.1007/s10856-005-4716-5

[29] Shanjani, Y., Hu, Y., Pilliar, R.M. and Toyserkani, E. (2011) Mechanical Characteristics of Solid-Freeform-Fabricated Porous Calcium Polyphosphate Structures with Oriented Stacked Layers. Acta Biomaterialia, 7, 1788-1796. http://dx.doi.org/10.1016/j.actbio.2010.12.017

[30] Klammert, U., Gbureck, U., Vorndran, E., Rödiger, J., Meyer-Marcotty, P. and Kübler, A.C. (2010) 3D Powder Printed Calcium Phosphate Implants for Reconstruction of Cranial and Maxillofacial Defects. Journal of Cranio-Maxillo-Facial Surgery, 38, 565-570. http://dx.doi.org/10.1016/j.jcms.2010.01.009

[31] Moroni, L. and Elisseeff, J.H. (2008) Biomaterials Engineered for Integration. Materials Today, 11, 44-51. http://dx.doi.org/10.1016/S1369-7021(08)70089-0

[32] Yeong, W., Chua, C., Leong, K. and Chandrasekaran, M. (2004) Rapid Prototyping in Tissue Engineering: Challenges and Potential. Trends in Biotechnology, 22, 643-652. http://dx.doi.org/10.1016/j.tibtech.2004.10.004

[33] Zein, I., Hutmacher, D.W., Cheng, K. and Hin, S. (2002) Fused Deposition Modeling of Novel Scaffold Architectures for Tissue Engineering Applications. Biomaterials, 23, 1169-1185. http://dx.doi.org/10.1016/S0142-9612(01)00232-0

[34] Porter, J.R., Ruckh, T.T. and Popat, K.C. (2009) Bone Tissue Engineering: A Review in Bone Biomimetics and Drug Delivery Strategies. Biotechnology Progress, 25, 1539-1560. http://dx.doi.org/10.1002/btpr.246

[35] Bose, S., Vahabzadeh, S. and Bandyopadhyay, A. (2013) Bone Tissue Engineering Using 3D Printing. Materials Today, 16, 496-504. http://dx.doi.org/10.1016/j.mattod.2013.11.017

[36] Kiebzak, G.M. (1991) Age-Related Bone Changes. Experimental Gerontology, 26, 171-187. http://dx.doi.org/10.1016/0531-5565(91)90010-J

[37] Santos, C.F.L., Silva, A.P., Lopes, L., Pires, I. and Correia, I.J. (2012) Design and Production of Sintered $\beta$-Tricalcium Phosphate 3D Scaffolds for Bone Tissue Regeneration. Materials Science and Engineering: C, 32, 1293-1298. http://dx.doi.org/10.1016/j.msec.2012.04.010

[38] Currey, J.D. (2004) Tensile Yield in Compact Bone Is Determined by Strain, Post-Yield Behaviour by Mineral Content. Journal of Biomechanics, 37, 549-556. http://dx.doi.org/10.1016/j.jbiomech.2003.08.008

[39] Sturm, S., Zhou, S., Mai, Y.W. and Li, Q. (2010) On Stiffness of Scaffolds for Bone Tissue Engineering-A Numerical Study. Journal of Biomechanics, 43, 1738-1744. http://dx.doi.org/10.1016/j.jbiomech.2010.02.020

[40] Arealis, G. and Nikolaou, V.S. (2015) Bone Printing: New Frontiers in the Treatment of Bone Defects. Injury, 46, S20S22. http://dx.doi.org/10.1016/s0020-1383(15)30050-4

[41] Wang, P., Zhao, L., Liu, J., Weir, M.D., Zhou, X. and Xu, H.H.K. (2014) Bone Tissue Engineering via Nanostructured Calcium Phosphate Biomaterials and Stem Cells. Bone Research, 2, 14017-14030. http://dx.doi.org/10.1038/boneres.2014.17

[42] Giannoudis, P., Dinopoulos, H. and Tsiridis, E. (2005) Bone Substitutes: An Update. Injury, 36, S20-S27. http://dx.doi.org/10.1016/j.injury.2005.10.006

[43] Laurencin, C., Khan, Y. and El-Amin, S.F. (2006) Bone Graft Substitutes. Expert Review of Medical Devices, 3, 49-57. http://dx.doi.org/10.1586/17434440.3.1.49

[44] Navarro, M., Michiardi, A., Castan, O. and Planell, J.A. (2008) Biomaterials in Orthopaedics. Journal of the Royal Society Interface, 5, 1137-1158. http://dx.doi.org/10.1098/rsif.2008.0151

[45] Fuchs, J.R., Nasseri, B.A. and Vacanti, J.P. (2001) Tissue Engineering: A 21st Century Solution to Surgical Reconstruction. The Annals of Thoracic Surgery, 72, 577-591. http://dx.doi.org/10.1016/S0003-4975(01)02820-X

[46] Chaignaud, B.E., Langer, R. and Vacanti, J.P. (1996) Polymer Scaffolds and Cells. 1-14.

[47] Kim, D.H., Rhim, R., Li, L., Martha, J., Swaim, B.H., Banco, R.J., et al. (2009) Prospective Study of Iliac Crest Bone Graft Harvest Site Pain and Morbidity. The Spine Journal, 9, 886-892. http://dx.doi.org/10.1016/j.spinee.2009.05.006 
[48] Kroeze, R.J., Helder, M.N., Govaert, L.E. and Smit, T.H. (2009) Biodegradable Polymers in Bone Tissue Engineering. Materials (Basel), 2, 833-856. http://dx.doi.org/10.3390/ma2030833

[49] Naughton, G.K., Tolbert, W.R. and Grillot, T.M. (1995) Emerging Developments in Tissue Engineering and Cell Technology. Tissue Engineering, 1, 211-219. http://dx.doi.org/10.1089/ten.1995.1.211

[50] Duan, B. and Wang, M. (2010) Customized Ca-P/PHBV Nanocomposite Scaffolds for Bone Tissue Engineering: Design, Fabrication, Surface Modification and Sustained Release of Growth Factor. Journal of the Royal Society Interface, 7, 615-629. http://dx.doi.org/10.1098/rsif.2010.0127.focus

[51] Rezwan, K., Chen, Q.Z., Blaker, J.J. and Roberto, A. (2006) Biodegradable and Bioactive Porous Polymer/Inorganic Composite Scaffolds for Bone Tissue Engineering. Biomaterials, 27, 3413-3431. http://dx.doi.org/10.1016/j.biomaterials.2006.01.039

[52] Salgado, A.J., Coutinho, O.P. and Reis, R.L. (2004) Bone Tissue Engineering: State of the Art and Future Trends. Macromolecular Bioscience, 4, 743-765. http://dx.doi.org/10.1002/mabi.200400026

[53] Griffith, L.G. (2002) Tissue Engineering_Current Challenges and Expanding Opportunities. Science, 295, $1009-1014$. http://dx.doi.org/10.1126/science.1069210

[54] Cox, S.C., Thornby, J.A., Gibbons, G.J., Williams, M.A. and Mallick, K.K. (2015) 3D Printing of Porous Hydroxyapatite Scaffolds Intended for Use in Bone Tissue Engineering Applications. Materials Science and Engineering: C, 47, 237-247. http://dx.doi.org/10.1016/j.msec.2014.11.024

[55] Li, X., Wang, L., Fan, Y., Feng, Q., Cui, F. and Watari, F. (2013) Nanostructured Scaffolds for Bone Tissue Engineering. Journal of Biomedical Materials Research Part A, 101, 2424-2435. http://dx.doi.org/10.1002/jbm.a.34539

[56] Kuboki, Y., Takita, H., Kobayashi, D., Tsuruga, E., Inoue, M., Murata, M., et al. (1998) BMP-Induced Osteogenesis on the Surface of Hydroxyapatite with Geometrically Feasible and Nonfeasible Structures: Topology of Osteogenesis. Journal of Biomedical Materials Research Part A, 39, 190-199. http://dx.doi.org/10.1002/(SICI)1097-4636(199802)39:2<190::AID-JBM4>3.0.CO;2-K

[57] Woo, K.M., Chen, V.J. and Ma, P.X. (2003) Nano-Fibrous Scaffolding Architecture Selectively Enhances Protein Adsorption Contributing to Cell Attachment. Journal of Biomedical Materials Research Part A, 67, 531-537. http://dx.doi.org/10.1002/jbm.a.10098

[58] Igual, R., Medrano, C. and Plaza, I. (2013) Challenges, Issues and Trends in Fall Detection Systems. BioMedical Engineering OnLine, 12, 66. http://dx.doi.org/10.1186/1475-925X-12-66

[59] Macchetta, A., Turner, I.G. and Bowen, C.R. (2009) Fabrication of HA/TCP Scaffolds with a Graded and Porous Structure Using a Camphene-Based Freeze-Casting Method. Acta Biomaterialia, 5, 1319-1327. http://dx.doi.org/10.1016/j.actbio.2008.11.009

[60] Chen, Q., Roether, J.A. and Boccaccini, A.R. (2008) Tissue Engineering Scaffolds from Bioactive Glass and Composite Materials. Topics in Tissue Engineering, 4, 1-27.

[61] Lin, H., Zhang, D., Alexander, P.G., Yang, G., Tan, J., Wai-Ming, A., et al. (2014) Application of Visible Light-Based Projection Stereolithography for Live Cell-Scaffold Fabrication with Designed Architecture. Biomaterials, 34, 331-339. http://dx.doi.org/10.1016/j.biomaterials.2012.09.048

[62] Murphy, S.V. and Atala, A. (2014) 3D Bioprinting of Tissues and Organs. Nature Biotechnology, 32, 773-785. http://dx.doi.org/10.1038/nbt.2958

[63] Tarafder, S., Banerjee, S., Bandyopadhyay, A. and Bose, S. (2011) Electrically Polarized Biphasic Calcium Phosphates: Adsorption and Release of Bovine Serum Albumin. Langmuir, 26, 16625-16629.

[64] Rechendorff, K., Hovgaard, M.B., Foss, M., Zhdanov, V.P. and Besenbacher, F. (2006) Enhancement of Protein Adsorption Induced by Surface Roughness. Langmuir, 22, 10885-10888. http://dx.doi.org/10.1021/la0621923

[65] Martin, J.Y., Schwartz, Z., Hummert, T.W., Schraub, D.M., Simpson, J., Lankford, J., et al. (1995) Effect of Titanium Surface Roughness on Proliferation, Differentiation, and Protein Synthesis of Human Osteoblast-Like Cells (MG63). Journal of Biomedical Materials Research Part A, 29, 389-401. http://dx.doi.org/10.1002/jbm.820290314

[66] Yuan, H., Yang, Z., Li, Y., Zhang, X., De Bruijn, J.D. and De Groot, K. (1998) Osteoinduction by Calcium Phosphate Biomaterials. Journal of Materials Science: Materials in Medicine, 9, 723-726. http://dx.doi.org/10.1023/A:1008950902047

[67] Barradas, A.M.C., Yuan, H., van Blitterswijk, C.A. and Habibovic, P. (2011) Osteoinductive Biomaterials: Current Knowledge of Properties, Experimental Models and Biological Mechanisms. European Cells \& Materials, 21, 407429.

[68] Chang, P., Liu, B., Liu, C., Chou, H., Ho, M., Liu, H., et al. (2007) Bone Tissue Engineering with Novel rhBMP2PLLA Composite Scaffolds. Journal of Biomedical Materials Research Part A, 81, 771-780. http://dx.doi.org/10.1002/jbm.a.31031 
[69] Perez, R.A. and Mestres, G. (2015) Role of Pore Size and Morphology in Musculo-Skeletal Tissue Regeneration. Materials Science and Engineering: C, 61, 922-939. http://dx.doi.org/10.1016/j.msec.2015.12.087

[70] Lee, J.W., Ahn, G., Cho, D.W. and Kim, J.Y. (2010) Evaluating Cell Proliferation Based on Internal Pore Size and 3D Scaffold Architecture Fabricated Using Solid Freeform Fabrication Technology. Journal of Materials Science: Materials in Medicine, 21, 3195-3205. http://dx.doi.org/10.1007/s10856-010-4173-7

[71] Lim, T.C., Chian, K.S. and Leong, K.F. (2010) Cryogenic Prototyping of Chitosan Scaffolds with Controlled Micro and Macro Architecture and Their Effect on in Vivo Neo-Vascularization and Cellular Infiltration. Journal of Biomedical Materials Research Part A, 94, 1303-1311. http://dx.doi.org/10.1002/jbm.a.32747

[72] Gbureck, U., Hölzel, T., Doillon, C.J., Müller, F.A. and Barralet, J.E. (2007) Direct Printing of Bioceramic Implants with Spatially Localized Angiogenic Factors. Advanced Materials, 19, 795-800. http://dx.doi.org/10.1002/adma.200601370

[73] Jonathan, G. and Karim, A. (2016) 3D Printing in Pharmaceutics: A New Tool for Designing Customized Drug Delivery Systems. International Journal of Pharmaceutics, 499, 376-394. http://dx.doi.org/10.1016/j.ijpharm.2015.12.071

[74] Gittens, S. and Uludag, H. (2001) Growth Factor Delivery for Bone Tissue Engineering. Journal of Drug Targeting, 9, 407-429. http://dx.doi.org/10.3109/10611860108998776

[75] Groeneveld, E.H.J., Van Den Bergh, J.P.A., Holzmann, P., Ten Bruggenkate, C.M., Tuinzing, D.B. and Burger, E.H. (1999) Mineralization Processes in Demineralized Bone Matrix Grafts in Human Maxillary Sinus Floor Elevations. Journal of Biomedical Materials Research Part A, 48, 393-402. http://dx.doi.org/10.1002/(SICI)1097-4636(1999)48:4<393::AID-JBM1>3.0.CO;2-C

[76] Hench, L.L. and Polak, J.M. (2002) Third-Generation Biomedical Materials. Science, 295, 1014-1017. http://dx.doi.org/10.1126/science.1067404

[77] Luginbuehl, V., Meinel, L., Merkle, H.P. and Gander, B. (2004) Localized Delivery of Growth Factors for Bone Repair. European Journal of Pharmaceutics and Biopharmaceutics, 58, 197-208. http://dx.doi.org/10.1016/j.ejpb.2004.03.004

[78] Tsivintzelis, I., Marras, S.I., Zuburtikudis, I. and Panayiotou, C. (2007) Porous Poly(L-Lactic Acid) Nanocomposite Scaffolds Prepared by Phase Inversion Using Supercritical $\mathrm{CO}_{2}$ as Antisolvent. Polymer (Guildf), 48, 6311-6318. http://dx.doi.org/10.1016/j.polymer.2007.08.021

[79] Serra, T., Planell, J.A. and Navarro, M. (2013) High-Resolution PLA-Based Composite Scaffolds via 3-D Printing Technology. Acta Biomaterialia, 9, 5521-5530. http://dx.doi.org/10.1016/j.actbio.2012.10.041

[80] Arifin, A., Sulong, A.B., Muhamad, N., Syarif, J. and Ramli, M.I. (2014) Material Processing of Hydroxyapatite and Titanium Alloy (HA/Ti) Composite as Implant Materials Using Powder Metallurgy: A Review. Materials \& Design, 55, 165-175. http://dx.doi.org/10.1016/j.matdes.2013.09.045

[81] Ben-Nissan, B. (2007) Natural Bioceramics: From Coral to Bone and Beyond. Current Opinion in Solid State and Materials Science, 7, 283-288. http://dx.doi.org/10.1016/j.cossms.2003.10.001

[82] Franco, J., Hunger, P., Launey, M.E., Tomsia, A.P. and Saiz, E. (2010) Direct Write Assembly of Calcium Phosphate Scaffolds Using a Water-Based Hydrogel. Acta Biomaterialia, 6, 218-228. http://dx.doi.org/10.1016/j.actbio.2009.06.031

[83] Fu, Q., Saiz, E. and Tomsia, A.P. (2011) Direct Ink Writing of Highly Porous and Strong Glass Scaffolds for LoadBearing Bone Defects Repair and Regeneration. Acta Biomaterialia, 7, 3547-3554. http://dx.doi.org/10.1016/j.actbio.2011.06.030

[84] Kim, H., Knowles, J.C. and Kim, H. (2004) Hydroxyapatite/Poly( $\varepsilon$-Caprolactone) Composite Coatings on Hydroxyapatite Porous Bone Scaffold for Drug Delivery. Biomaterials, 25, 1279-1287. http://dx.doi.org/10.1016/j.biomaterials.2003.07.003

[85] Martínez-Pérez, C.A., García-Montelongo, J., Garcia, P.E., Farias-Mancilla, J.R. and Monreal, H. (2012) Preparation of Hydroxyapatite Nanoparticles Facilitated by the Presence of $\beta$-Cyclodextrin. Journal of Alloys and Compounds, 536, S432-S436. http://dx.doi.org/10.1016/j.jallcom.2011.12.135

[86] Moradi, A., Dalilottojari, A., Pingguan-Murphy, B. and Djordjevic, I. (2013) Fabrication and Characterization of Elastomeric Scaffolds Comprised of a Citric Acid-Based Polyester/Hydroxyapatite Microcomposite. Materials \& Design, 50, 446-450. http://dx.doi.org/10.1016/j.matdes.2013.03.026

[87] Rajzer, I. (2014) Fabrication of Bioactive Polycaprolactone/Hydroxyapatite Scaffolds with Final Bilayer Nano-/MicroFibrous Structures for Tissue Engineering Application. Journal of Materials Science, 49, 5799-5807. http://dx.doi.org/10.1007/s10853-014-8311-3

[88] Sebdani, M.M. and Fathi, M.H. (2011) Novel Hydroxyapatite-Forsterite-Bioglass Nanocomposite Coatings with Improved Mechanical Properties. Journal of Alloys and Compounds, 509, 2273-2276. http://dx.doi.org/10.1016/j.jallcom.2010.10.202 
[89] Vallet-Regí, M. and González-Calbet, J.M. (2004) Calcium Phosphates as Substitution of Bone Tissues. Progress in Solid State Chemistry, 32, 1-31. http://dx.doi.org/10.1016/j.progsolidstchem.2004.07.001

[90] Boccaccini, A.R., Blaker, J.J., Maquet, V., Day, R.M. and Je, R. (2005) Preparation and Characterization of Poly(Lactide-co-Glycolide) (PLGA) and PLGA/Bioglass ${ }^{\circledR}$ Composite Tubular foam Scaffolds for Tissue Engineering Applications. Materials Science and Engineering: C, 25, 23-31. http://dx.doi.org/10.1016/j.msec.2004.03.002

[91] Hench, L.L. (1998) Feature 1705. Stress: The International Journal on the Biology of Stress, 81, 1705-1728.

[92] Senatov, F.S., Niaza, K.V., Zadorozhnyy, M.Y., Maksimkin, A.V., Kaloshkin, S.D. and Estrin, Y.Z. (2016) Mechanical Properties and Shape Memory Effect of 3D-Printed PLA-Based Porous Scaffolds. Journal of the Mechanical Behavior of Biomedical Materials, 57, 139-148. http://dx.doi.org/10.1016/j.jmbbm.2015.11.036

[93] Zhang, R. and Ma, P.X. (2004) Biomimetic Polymer/Apatite Composite Scaffolds for Mineralized Tissue Engineering. Macromolecular Bioscience, 4, 100-111. http://dx.doi.org/10.1002/mabi.200300017

[94] Raghoebar, G.M., Liem, R.S.B., Bos, R.R.M., Van Der Wal, J.E. and Vissink, A. (2006) Resorbable Screws for Fixation of Autologous Bone Grafts. Clinical Oral Implants Research, 17, 288-293. http://dx.doi.org/10.1111/j.1600-0501.2005.01200.x

[95] Kim, K.K. and Pack, D.W. (2006) Microspheres for Drug Delivery. In: Ferrari, M., Lee, A.P. and Lee, L.J., Eds., BioMEMS and Biomedical Nanotechnology, Springer, New York, 19-50. http://dx.doi.org/10.1007/978-0-387-25842-3_2

[96] Lassalle, V. and Ferreira, M.L. (2007) PLA Nano- and Microparticles for Drug Delivery: An Overview of the Methods of Preparation. Macromolecular Bioscience, 7, 767-783. http://dx.doi.org/10.1002/mabi.200700022

[97] Mora-Huertas, C.E., Fessi, H. and Elaissari, A. (2010) Polymer-Based Nanocapsules for Drug Delivery. International Journal of Pharmaceutics 385, 113-142. http://dx.doi.org/10.1016/j.ijpharm.2009.10.018

[98] Ouchi, T., Saito, T., Kontani, T. and Ohya, Y. (2004) Encapsulation and/or Release Behavior of Bovine Serum Albumin within and from Polylactide-Grafted Dextran Microspheres. Macromolecular Bioscience, 4, 458-463. http://dx.doi.org/10.1002/mabi.200300106

[99] Vilar, G., Tulla-Puche, J. and Albericio, F. (2012) Polymers and Drug Delivery Systems. Current Drug Delivery, 9, 367-394. http://dx.doi.org/10.2174/156720112801323053

[100] Shah Mohammadi, M., Bureau, M.N. and Nazhat, S.N. (2014) Polylactic Acid (PLA) Biomedical Foams for Tissue Engineering. In: Netti, P., Ed., Biomedical Foams for Tissue Engineering Applications, Woodhead Publishing Limited, Cambridge, 313-334. http://dx.doi.org/10.1533/9780857097033.2.313

[101] Tanodekaew, S., Channasanon, S. and Kaewkong, P. (2013) PLA-HA Scaffolds: Preparation and Bioactivity. Procedia Engineering, 59, 144-149. http://dx.doi.org/10.1016/j.proeng.2013.05.104

[102] Bonfield, W. (2006) Designing Porous Scaffolds for Tissue Engineering. Philosophical Transactions of the Royal Society A, 364, 227-232. http://dx.doi.org/10.1098/rsta.2005.1692

[103] Pérez, R.A., Won, J., Knowles, J.C. and Kim, H. (2013) Naturally and Synthetic Smart Composite Biomaterials for Tissue Regeneration. Advanced Drug Delivery Reviews, 65, 471-496. http://dx.doi.org/10.1016/j.addr.2012.03.009

[104] Wegst, U.G.K. and Ashby, M.F. (2004) The Mechanical Efficiency of Natural Materials. Philosophical Magazine, 21, 2167-2181. http://dx.doi.org/10.1080/14786430410001680935

[105] Venugopal, J., Prabhakaran, M.P., Zhang, Y., Low, S., Choon, A.T. and Ramakrishna, S. (2010) Biomimetic Hydroxyapatite-Containing Composite Nanofibrous Substrates for Bone Tissue Engineering. Philosophical Transactions of the Royal Society A, 368, 2065-2081. http://dx.doi.org/10.1098/rsta.2010.0012

[106] Van Vlierberghe, S., Dubruel, P. and Schacht, E. (2011) Biopolymer-Based Hydrogels as Scaffolds for Tissue Engineering Applications: A Review. Biomacromolecules, 12, 1387-1408. http://dx.doi.org/10.1021/bm200083n

[107] Ray, S.S. and Okamoto, M. (2003) Polymer/Layered Silicate Nanocomposites: A Review from Preparation to Processing. Progress in Polymer Science, 28, 1539-1641. http://dx.doi.org/10.1016/j.progpolymsci.2003.08.002

[108] Armentano, I., Bitinis, N., Fortunati, E., Mattioli, S., Rescignano, N., Verdejo, R., et al. (2013) Multifunctional Nanostructured PLA Materials for Packaging and Tissue Engineering. Progress in Polymer Science, 38, 1720-1747. http://dx.doi.org/10.1016/j.progpolymsci.2013.05.010

[109] Zhang, L. and Webster, T.J. (2009) Nanotechnology and Nanomaterials: Promises for Improved Tissue Regeneration. Nano Today, 4, 66-80. http://dx.doi.org/10.1016/j.nantod.2008.10.014

[110] Karageorgiou, V. and Kaplan, D. (2005) Porosity of 3D Biomaterial Scaffolds and Osteogenesis. Biomaterials, 26, 5474-5491. http://dx.doi.org/10.1016/j.biomaterials.2005.02.002

[111] Kubinová, S. and Syková, E. (2010) Nanotechnologies in Regenerative Medicine. Minimally Invasive Therapy \& Allied Technologies, 19, 144-156. http://dx.doi.org/10.3109/13645706.2010.481398 
[112] Hule, R.A. and Pochan, D.J. (2007) Polymer Nanocomposites for Biomedical. MRS Bulletin, 32, 354-358. http://dx.doi.org/10.1557/mrs2007.235

[113] Murugan, R. and Ramakrishna, S. (2005) Development of Nanocomposites for Bone Grafting. Composites Science and Technology, 65, 2385-2406. http://dx.doi.org/10.1016/j.compscitech.2005.07.022

[114] Tjong, S.C. (2006) Structural and Mechanical Properties of Polymer Nanocomposites. Materials Science and Engineering: R: Reports, 53, 73-197. http://dx.doi.org/10.1016/j.mser.2006.06.001

[115] Cho, J., Joshi, M.S. and Sun, C.T. (2006) Effect of Inclusion Size on Mechanical Properties of Polymeric Composites with Micro and Nano Particles. Composites Science and Technology, 66, 1941-1952. http://dx.doi.org/10.1016/j.compscitech.2005.12.028

[116] Jo, J., Lee, E., Shin, D., Kim, H., Kim, H., Koh, Y., et al. (2009) In Vitro/in Vivo Biocompatibility and Mechanical Properties of Bioactive Glass Nanofiber and Poly( $\varepsilon$-Caprolactone) Composite Materials. Journal of Biomedical Materials Research Part B: Applied Biomaterials, 91, 213-220. http://dx.doi.org/10.1002/jbm.b.31392

[117] Davis, H.E. and Leach, J.K. (2008) Hybrid and Composite Biomaterials in Tissue Engineering. In: Ashammakhi, N, Ed., Topics in Multifunctional Biomaterials and Devices, 1-26.

[118] Bulte, J.W.M., Douglas, T., Witwer, B., Zhang, S., Strable, E., Lewis, B.K., et al. (2001) Magnetodendrimers Allow Endosomal Magnetic Labeling and in Vivo Tracking of Stem Cells. Nature Biotechnology, 19, 1141-1147. http://dx.doi.org/10.1038/nbt1201-1141

[119] Harrison, B.S. and Atala, A. (2007) Carbon Nanotube Applications for Tissue Engineering. Biomaterials, 28, $344-353$. http://dx.doi.org/10.1016/j.biomaterials.2006.07.044

[120] Gleiter, H. (2000) Nanostructured Materials: Basic Concepts and Microstructure. Acta Materialia, 48, 1-29. http://dx.doi.org/10.1016/S1359-6454(99)00285-2

[121] Mothersill, C., Seymour, C.B. and O’Brien, A. (1991) Induction of c-Myc Oncoprotein and of Cellular Proliferation by Radiation in Normal Human Urothelial Cultures. Anticancer Research, 11, 1609-1612.

[122] Billiet, T., Vandenhaute, M., Schelfhout, J., Van Vlierberghe, S. and Dubruel, P. (2012) A Review of Trends and Limitations in Hydrogel-Rapid Prototyping for Tissue Engineering. Biomaterials, 33, 6020-6041. http://dx.doi.org/10.1016/j.biomaterials.2012.04.050

[123] Butscher, A., Bohner, M., Roth, C., Ernstberger, A., Heuberger, R., Doebelin, N., et al. (2012) Printability of Calcium Phosphate Powders for Three-Dimensional Printing of Tissue Engineering Scaffolds. Acta Biomaterialia, 8, 373-385. http://dx.doi.org/10.1016/j.actbio.2011.08.027

[124] Chumnanklang, R., Panyathanmaporn, T., Sitthiseripratip, K. and Suwanprateeb, J. (2007) 3D Printing of Hydroxyapatite: Effect of Binder Concentration in Pre-Coated Particle on Part Strength. Materials Science and Engineering: C, 27, 914-921. http://dx.doi.org/10.1016/j.msec.2006.11.004

[125] Kumar, S. and Kruth, J. (2010) Composites by Rapid Prototyping Technology. Materials \& Design, 31, 850-856. http://dx.doi.org/10.1016/j.matdes.2009.07.045

[126] Maleksaeedi, S., Eng, H., Wiria, F.E., Ha, T.M.H. and He, Z. (2014) Property Enhancement of 3D-Printed Alumina Ceramics Using Vacuum Infiltration. Journal of Materials Processing Technology, 214, 1301-1306. http://dx.doi.org/10.1016/j.jmatprotec.2014.01.019

[127] Kietzmann, J., Pitt, L. and Berthon, P. (2015) Disruptions, Decisions, and Destinations: Enter the Age of 3-D Printing and Additive Manufacturing. Business Horizons, 58, 209-215. http://dx.doi.org/10.1016/j.bushor.2014.11.005

[128] Stansbury, J.W. and Idacavage, M.J. (2015) 3D Printing with Polymers: Challenges among Expanding Options and Opportunities. Dental Materials, 32, 54-64. http://dx.doi.org/10.1016/j.dental.2015.09.018

[129] Berman, B., Zarb, F.G. and Hall, W. (2012) 3-D Printing: The New Industrial Revolution. Business Horizons, 55, 155162. http://dx.doi.org/10.1016/j.bushor.2011.11.003

[130] Melchels, F.P.W., Feijen, J. and Grijpma, D.W. (2010) A Review on Stereolithography and Its Applications in Biomedical Engineering. Biomaterials, 31, 6121-6130. http://dx.doi.org/10.1016/j.biomaterials.2010.04.050

[131] Stickland, M.T., Mckay, S. and Scanlon, T.J. (2003) The Development of a Three Dimensional Imaging System and Its Application in Computer Aided Design Workstations. Mechatronics, 13, 521-532. http://dx.doi.org/10.1016/S0957-4158(01)00052-6

[132] Watson, R.A. (2014) A Low-Cost Surgical Application of Additive Fabrication. Journal of Surgical Education, 71, 1417. http://dx.doi.org/10.1016/j.jsurg.2013.10.012

[133] Gebler, M., Uiterkamp, A.J.M.S. and Visser, C. (2014) A Global Sustainability Perspective on 3D Printing Technologies. Energy Policy, 74, 158-167. http://dx.doi.org/10.1016/j.enpol.2014.08.033

[134] Shafiee, A. and Atala, A. (2016) Printing Technologies for Medical Applications. Trends in Molecular Medicine, 22, 
254-265. http://dx.doi.org/10.1016/j.molmed.2016.01.003

[135] Yan, X. and Gu, P. (1996) A Review of Rapid Prototyping Technologies and Systems. Computer-Aided Design, 28, 307-316. http://dx.doi.org/10.1016/0010-4485(95)00035-6

[136] Yang, S., Yang, H., Chi, X., Evans, J.R.G., Thompson, I., Cook, R.J., et al. (2008) Rapid Prototyping of Ceramic Lattices for Hard Tissue Scaffolds. Materials \& Design, 29, 1802-1809. http://dx.doi.org/10.1016/j.matdes.2008.03.024

[137] Rezende, R.A., Kasyanov, V., Mironov, V. and Lopes, J.V. (2015) Organ Printing as an Information Technology. Procedia Engineering, 110, 151-158. http://dx.doi.org/10.1016/j.proeng.2015.07.023

[138] Malik, H.H., Darwood, A.R.J., Hons, B., Shaunak, S., Kulatilake, P., El-hilly, A.A., et al. (2015) Three-Dimensional Printing in Surgery: A Review of Current Surgical Applications. Journal of Surgical Research, 199, 512-522. http://dx.doi.org/10.1016/j.jss.2015.06.051

[139] Pati, F., Shim, J., Lee, J. and Cho, D. (2013) 3D Printing of Cell-Laden Constructs for Heterogeneous Tissue Regeneration. Manufacturing Letters, 1, 49-53. http://dx.doi.org/10.1016/j.mfglet.2013.09.004

[140] Zhang, W., Lian, Q., Li, D., Wang, K., Hao, D., Bian, W., et al. (2015) The Effect of Interface Microstructure on Interfacial Shear Strength for Osteochondral Scaffolds Based on Biomimetic Design and 3D Printing. Materials Science and Engineering: C, 46, 10-15. http://dx.doi.org/10.1016/j.msec.2014.09.042

[141] Kruth, J., Levy, G., Klocke, F. and Childs, T.H.C. (2007) Consolidation Phenomena in Laser and Powder-Bed Based Layered Manufacturing. CIRP Annals-Manufacturing Technology, 56, 730-759. http://dx.doi.org/10.1016/j.cirp.2007.10.004

[142] Melchels, F.P.W., Feijen, J. and Grijpma, D.W. (2009) A Poly(D,L-Lactide) Resin for the Preparation of Tissue Engineering Scaffolds by Stereolithography. Biomaterials, 30, 3801-3809. http://dx.doi.org/10.1016/j.biomaterials.2009.03.055

[143] De Ciurana, J., Serenó, L. and Vallès, È. (2013) Selecting Process Parameters in RepRap Additive Manufacturing System for PLA Scaffolds Manufacture. Procedia CIRP, 5, 152-157. http://dx.doi.org/10.1016/j.procir.2013.01.031

[144] Gauvin, R., Chen, Y., Woo, J., Soman, P., Zorlutuna, P., Nichol, J.W., et al. (2012) Biomaterials Microfabrication of Complex Porous Tissue Engineering Scaffolds Using 3D Projection Stereolithography. Biomaterials, 33, 3824-3834. http://dx.doi.org/10.1016/j.biomaterials.2012.01.048

[145] Okabe, K., Yamada, Y., Ito, K., Kohgo, T., Yoshimi, R. and Ueda, M. (2009) Injectable Soft-Tissue Augmentation by Tissue Engineering and Regenerative Medicine with Human Mesenchymal Stromal Cells, Platelet-Rich Plasma and Hyaluronic Acid Scaffolds. Cytotherapy, 11, 307-316. http://dx.doi.org/10.1080/14653240902824773

[146] Kim, S.S., Utsunomiya, H., Koski, J.A., Wu, B.M., Cima, M.J., Sohn, J., et al. (1998) Survival and Function of Hepatocytes on a Novel Three-Dimensional Synthetic Biodegradable Polymer Scaffold with an Intrinsic Network of Channels. Annals of Surgery, 228, 8-13. http://dx.doi.org/10.1097/00000658-199807000-00002

[147] Park, J.S., Chu, J.S., Tsou, A.D., Diop, R., Wang, A. and Li, S. (2012) The Effect of Matrix Stiffness on the Differentiation of Mesenchymal Stem Cells in Response to TGF- $\beta$. Biomaterials, 32, 3921-3930. http://dx.doi.org/10.1016/j.biomaterials.2011.02.019

[148] Zeltinger, J., Sherwood, J.K., Graham, D.A., Müeller, R. and Griffith, L.G. (2001) Effect of Pore Size and Void Fraction on Cellular Adhesion, Proliferation, and Matrix Deposition. Tissue Engineering, 7, 557-572. http://dx.doi.org/10.1089/107632701753213183

[149] Seliktar, D., Dikovsky, D. and Napadensky, E. (2013) Bioprinting and Tissue Engineering: Recent Advances and Future Perspectives. Israel Journal of Chemistry, 53, 795-804. http://dx.doi.org/10.1002/ijch.201300084

[150] Tang, D., Tare, R.S., Yang, L., Williams, D.F., Ou, K. and Oreffo, R.O.C. (2016) Biofabrication of Bone Tissue: Approaches, Challenges and Translation for Bone Regeneration. Biomaterials, 83, 363-382. http://dx.doi.org/10.1016/j.biomaterials.2016.01.024

[151] Odde, D.J. and Renn, M.J. (1999) Laser-Guided Direct Writing for Applications in Biotechnology. Nanotechnology, 7799, 385-389. http://dx.doi.org/10.1016/s0167-7799(99)01355-4

[152] Boland, T., Mironov, V., Gutowska, A., Roth, E.A. and Markwald, R.R. (2003) Cell and Organ Printing 2: Fusion of Cell Aggregates in Three-Dimensional Gels. The Anatomical Record, 272A, 497-502. http://dx.doi.org/10.1002/ar.a.10059

[153] Saunders, R., Bosworth, L., Gough, J., Derby, B., Reis, N., Materials, E., et al. (2004) Selective Cell Delivery for 3D Tissue Culture and Engineering. European Cells \& Materials, 7, 84.

[154] Yang, S., Leong, K.-F., Du, Z. and Chua, C.-K. (2002) The Design of Scaffolds for Use in Tissue Engineering. Part II. Rapid Prototyping Techniques. Tissue Engineering, 8, 1-11. http://dx.doi.org/10.1089/107632702753503009

[155] Beahm, E.K., Walton, R.L. and Patrick, C.W. (2003) Progress in Adipose Tissue Construct Development. Clinics in 
Plastic Surgery, 30, 547-558. http://dx.doi.org/10.1016/S0094-1298(03)00072-5

[156] Lee, Y.B., Polio, S., Lee, W., Dai, G. and Yoo, S. (2010) Bio-Printing of Collagen and VEGF-Releasing Fibrin Gel Scaffolds for Neural Stem Cell Culture. Experimental Neurology, 223, 645-652. http://dx.doi.org/10.1016/j.expneurol.2010.02.014

[157] Shim, J., Kim, S.E., Park, J.Y. and Kundu, J. (2014) Scaffolds with Long-Term Delivery for Enhanced Bone Regeneration in a Rabbit Diaphyseal Defect. Tissue Engineering Part A, 20, 1980-1992. http://dx.doi.org/10.1089/ten.tea.2013.0513

[158] Flynn, L.E. (2010) The Use of Decellularized Adipose Tissue to Provide an Inductive Microenvironment for the Adipogenic Differentiation of Human Adipose-Derived Stem Cells. Biomaterials, 31, 4715-4724. http://dx.doi.org/10.1016/j.biomaterials.2010.02.046

[159] Gilbert, T.W., Sellaro, T.L. and Badylak, S.F. (2006) Decellularization of Tissues and Organs. Biomaterials, 27, 36753683. http://dx.doi.org/10.1016/j.biomaterials.2006.02.014

[160] Pati, F., Ha, D., Jang, J., Ho, H. and Rhie, J. (2015) Biomimetic 3D Tissue Printing for Soft Tissue Regeneration. Biomaterials, 62, 164-175. http://dx.doi.org/10.1016/j.biomaterials.2015.05.043

[161] Debnath, J. and Brugge, J.S. (2005) Modelling Glandular Epithelial Cancers in Three Dimensional Cultures. Nature Reviews Cancer, 5, 675-688. http://dx.doi.org/10.1038/nrc1695

[162] Vargo-gogola, T. and Rosen, J.M. (2007) Modelling Breast Cancer: One Size Does Not Fit All. Nature Reviews Cancer, 7, 659-672. http://dx.doi.org/10.1038/nrc2193

[163] Rijal, G. and Li, W. (2016) 3D Scaffolds in Breast Cancer Research. Biomaterials, 81, 135-156. http://dx.doi.org/10.1016/j.biomaterials.2015.12.016

[164] Xu, T., Zhao, W., Zhu, J., Albanna, M.Z., Yoo, J.J. and Atala, A. (2013) Biomaterials Complex Heterogeneous Tissue Constructs Containing Multiple Cell Types Prepared by Inkjet Printing Technology. Biomaterials, 34, 130-139. http://dx.doi.org/10.1016/j.biomaterials.2012.09.035

[165] Lee, V.K., Lanzi, A.M., Ngo, H., Loo, S.C., Vincent, P.A. and Dai, G. (2014) Generation of Multi-Scale Vascular Network System Within 3D Hydrogel Using 3D Bio-Printing Technology. Cellular and Molecular Bioengineering, 7, 460-472. http://dx.doi.org/10.1007/s12195-014-0340-0

[166] Paulsen, S.J. and Miller, J.S. (2015) Tissue Vascularization through 3D Printing: Will Technology Bring Us Flow? Developmental Dynamics, 244, 629-640. http://dx.doi.org/10.1002/dvdy.24254

[167] Hopkinson, N. and Dickens, P.M. (2006) Rapid Manufacturing: An Industrial for the Digital Age.

[168] Chua, C.K., Leong, K.F., Tan, K.H., Wiria, F.E. and Cheah, C.M. (2004) Development of Tissue Scaffolds Using Selective Laser Sintering of Polyvinyl Alcohol/Hydroxyapatite Biocomposite for Craniofacial and Joint Defects. Journal of Materials Science: Materials in Medicine, 15, 1113-1121. http://dx.doi.org/10.1023/B:JMSM.0000046393.81449.a5

[169] Shuai, C., Gao, C., Nie, Y., Hu, H., Zhou, Y. and Peng, S. (2011) Structure and Properties of Nano-Hydroxypatite Scaffolds for Bone Tissue Engineering with a Selective Laser Sintering System. Nanotechnology, 22, 285703. http://dx.doi.org/10.1088/0957-4484/22/28/285703

[170] Tan, K.H., Chua, C.K., Leong, K.F., Cheah, C.M., Cheang, P., Bakar, M.S.A., et al. (2003) Scaffold Development Using Selective Laser Sintering of Polyetheretherketone-Hydroxyapatite Biocomposite Blends. Biomaterials, 24, 31153123. http://dx.doi.org/10.1016/S0142-9612(03)00131-5

[171] Soe, S.P., Eyers, D.R. and Setchi, R. (2013) Assessment of Non-Uniform Shrinkage in the Laser Sintering of Polymer Materials. The International Journal of Advanced Manufacturing Technology, 68, 111-125. http://dx.doi.org/10.1007/s00170-012-4712-0

[172] Dupin, S., Lame, O., Barrès, C. and Charmeau, J. (2012) Microstructural Origin of Physical and Mechanical Properties of Polyamide 12 Processed by Laser Sintering. European Polymer Journal, 48, 1611-1621. http://dx.doi.org/10.1016/j.eurpolymj.2012.06.007

[173] Butscher, A., Bohner, M., Hofmann, S., Gauckler, L. and Müller, R. (2011) Structural and Material Approaches to Bone Tissue Engineering in Powder-Based Three-Dimensional Printing. Acta Biomaterialia, 7, 907-920. http://dx.doi.org/10.1016/j.actbio.2010.09.039

[174] Hull, C.W. and UVP, Inc. (1986) Apparatus for Production of Three-Dimensional Objects by Stereolithography. US Pat 4575330.

[175] Gittard, S.D. and Narayan, R.J. (2011) Laser Direct Writing of Micro- and Nano-Scale Medical Devices. Expert Review of Medical Devices, 7, 343-356. http://dx.doi.org/10.1586/erd.10.14

[176] Selimis, A., Mironov, V. and Farsari, M. (2015) Microelectronic Engineering Direct Laser Writing: Principles and Materials for Scaffold 3D Printing. Microelectronic Engineering, 132, 83-89. http://dx.doi.org/10.1016/j.mee.2014.10.001 
[177] Cooke, M.N., Fisher, J.P., Dean, D., Rimnac, C. and Mikos, A.G. (2002) Use of Stereolithography to Manufacture Critical-Sized 3D Biodegradable Scaffolds for Bone Ingrowth. Journal of Biomedical Materials Research Part B: Applied Biomaterials, 64, 65-69.

[178] Fisher, J.P., Vehof, J.W.M., Dean, D., Van der Waerden, J.P.C.M., Holland, T.A., Mikos, A.G., et al. (2002) Soft and Hard Tissue Response to Photocrosslinked Poly(Propylene Fumarate) Scaffolds in a Rabbit Model. Journal of Biomedical Materials Research Part A, 59, 547-556. http://dx.doi.org/10.1002/jbm.1268

[179] Mapili, G., Lu, Y., Chen, S. and Roy, K. (2005) Laser-Layered Microfabrication of Spatially Patterned Functionalized Tissue-Engineering Scaffolds. Journal of Biomedical Materials Research Part B: Applied Biomaterials, 75, 414-424. http://dx.doi.org/10.1002/jbm.b.30325

[180] Ikehata, H., Ono, T., Uv, U. and Tls, U.V.A. (2011) The Mechanisms of UV Mutagenesis. Journal of Radiation Research, 52, 115-125. http://dx.doi.org/10.1269/jrr.10175

[181] Seol, Y., Park, D.Y., Park, J.Y., Kim, S.W. and Park, S.J. (2013) A New Method of Fabricating Robust Freeform 3D Ceramic Scaffolds for Bone Tissue Regeneration. Biotechnology and Bioengineering, 110, 1444-1455. http://dx.doi.org/10.1002/bit.24794

[182] Shor, L. (2007) Fabrication of Three-Dimensional Polycaprolactone/Hydroxyapatite Tissue Scaffolds and Osteoblast-Scaffold Interactions in Vitro. Biomaterials, 28, 5291-5297. http://dx.doi.org/10.1016/j.biomaterials.2007.08.018

[183] Postiglione, G., Natale, G., Griffini, G., Levi, M. and Turri, S. (2015) Conductive 3D Microstructures by Direct 3D Printing Of Polymer/Carbon Nanotube Nanocomposites via Liquid Deposition Modeling. Composites Part A: Applied Science and Manufacturing, 76, 110-114. http://dx.doi.org/10.1016/j.compositesa.2015.05.014

[184] Hunt, E.J., Zhang, C., Anzalone, N. and Pearce, J.M. (2015) Resources, Conservation and Recycling Polymer Recycling Codes for Distributed Manufacturing with 3-D Printers. Resources, Conservation and Recycling, 97, 24-30. http://dx.doi.org/10.1016/j.resconrec.2015.02.004

[185] Moroni, L., De Wijn, J.R. and Van Blitterswijk, C.A. (2006) 3D Fiber-Deposited Scaffolds for Tissue Engineering: Influence of Pores Geometry and Architecture on Dynamic Mechanical Properties. Biomaterials, 27, 974-985. http://dx.doi.org/10.1016/j.biomaterials.2005.07.023

[186] Guo, S., Gosselin, F., Guerin, N., Lanouette, A., Heuzey, M. and Therriault, D. (2013) Solvent-Cast Three-Dimensional Printing of Multifunctional Microsystems. Small, 9, 4118-4122. http://dx.doi.org/10.1002/smll.201300975

[187] Bergmann, C., Lindner, M., Zhang, W., Koczur, K., Kirsten, A., Telle, R., et al. (2010) 3D Printing of Bone Substitute Implants Using Calcium Phosphate and Bioactive Glasses. Journal of the European Ceramic Society, 30, 2563-2537. http://dx.doi.org/10.1016/j.jeurceramsoc.2010.04.037

[188] Vaezi, M. and Chua, C.K. (2011) Effects of Layer Thickness and Binder Saturation Level Parameters on 3D Printing Process. The International Journal of Advanced Manufacturing Technology, 53, 275-284. http://dx.doi.org/10.1007/s00170-010-2821-1

[189] Boland, T., Xu, T., Damon, B. and Cui, X. (2006) Application of Inkjet Printing to Tissue Engineering. Biotechnology Journal, 9, 910-917. http://dx.doi.org/10.1002/biot.200600081

[190] Chia, H.N. and Wu, B.M. (2015) Recent Advances in 3D Printing of Biomaterials. Journal of Biological Engineering, 9, 4. http://dx.doi.org/10.1186/s13036-015-0001-4

[191] Nakamura, M., Kobayashi, A., Takagi, F., Watanabe, A., Hiruma, Y., Ohuchi, K., et al. (2005) Biocompatible Inkjet Printing Technique for Designed Seeding of Individual Living Cells. Tissue Engineering, 11, 1658-1666.

[192] Lee, M., Dunn, J.C.Y. and Wu, B.M. (2005) Scaffold Fabrication by Indirect Three-Dimensional Printing. Biomaterials, 26, 4281-4289. http://dx.doi.org/10.1016/j.biomaterials.2004.10.040

[193] Wu, B.M., Borland, S.W., Giordano, R.A., Cima, L.G., Sachs, E.M. and Cima, M.J. (1996) Solid Free-Form Fabrication of Drug Delivery Devices. Journal of Controlled Release, 40, 77-87. http://dx.doi.org/10.1016/0168-3659(95)00173-5

[194] Asadi-eydivand, M., Solati-hashjin, M. and Farzad, A. (2016) Robotics and Computer-Integrated Manufacturing Effect of Technical Parameters on Porous Structure and Strength of 3D Printed Calcium Sulfate Prototypes. Robotics and Computer-Integrated Manufacturing, 37, 57-67. http://dx.doi.org/10.1016/j.rcim.2015.06.005

[195] Chu, T.G., Hollister, S.J., Halloran, J.W. and Feinberg, S.E. (2002) Manufacturing and Characterization of 3-D Hydroxyapatite Bone Tissue Engineering. Annals of the New York Academy of Sciences, 117, 114-117. http://dx.doi.org/10.1111/j.1749-6632.2002.tb03061.x

[196] Liu, C., Xia, Z., Triffitt, J., Hulley, P.A. and Czernuska, J.T. (2008) Novel 3D Collagen Scaffolds Fabricated by Indirect Printing Technique for Tissue Engineering. Journal of Biomedical Materials Research Part B: Applied Biomaterials, 85, 519-528. http://dx.doi.org/10.1002/jbm.b.30975

[197] Taboas, J.M., Maddox, R.D., Krebsbach, P.H. and Hollister, S.J. (2003) Indirect Solid Free form Fabrication of Local 
and Global Porous, Biomimetic and Composite 3D Polymer-Ceramic Scaffolds. Biomaterials, 24, 181-194. http://dx.doi.org/10.1016/S0142-9612(02)00276-4

[198] Tamjid, E. and Simchi, A. (2015) Fabrication of a Highly Ordered Hierarchically Designed Porous Nanocomposite via Indirect 3D Printing: Mechanical Properties and in Vitro Cell Responses. Materials \& Design, 88, 924-931. http://dx.doi.org/10.1016/j.matdes.2015.08.133

[199] Deisinger, U., Hamisch, S., Schumacher, M., Uhl, F., Detsch, R. and Ziegler, G. (2008) Fabrication of Tailored Hydroxyapatite Scaffolds: Comparison between a Direct and an Indirect Rapid Prototyping Technique. Key Engineering Materials, 361-363, 915-918. http://dx.doi.org/10.4028/www.scientific.net/KEM.361-363.915

[200] Lu, K., Hiser, M. and Wu, W. (2009) Effect of Particle Size on Three Dimensional Printed Mesh Structures. Powder Technology, 192, 178-183. http://dx.doi.org/10.1016/j.powtec.2008.12.011

[201] Turker, M., Godlinski, D. and Petzoldt, F. (2008) Effect of Production Parameters on the Properties of IN 718 Superalloy by Three-Dimensional Printing. Materials Characterization, 59, 1728-1735. http://dx.doi.org/10.1016/j.matchar.2008.03.017

[202] Zhou, Z., Buchanan, F., Mitchell, C. and Dunne, N. (2014) Printability of Calcium Phosphate: Calcium Sulfate Powders for the Application of Tissue Engineered Bone Scaffolds Using the 3D Printing Technique. Materials Science and Engineering: C, 38, 1-10. http://dx.doi.org/10.1016/j.msec.2014.01.027

\section{Submit or recommend next manuscript to SCIRP and we will provide best service for you:}

Accepting pre-submission inquiries through Email, Facebook, LinkedIn, Twitter, etc. A wide selection of journals (inclusive of 9 subjects, more than 200 journals)

Providing 24-hour high-quality service

User-friendly online submission system

Fair and swift peer-review system

Efficient typesetting and proofreading procedure

Display of the result of downloads and visits, as well as the number of cited articles

Maximum dissemination of your research work

Submit your manuscript at: http://papersubmission.scirp.org/ 